Discussion Paper No. 08-038

\title{
Déjà Vu?
}

\section{Short-Term Training in Germany 1980-1992 and 2000-2003}

Bernd Fitzenberger, Olga Orlyanskaya, Aderonke Osikominu, and Marie Waller

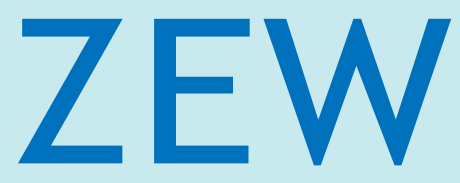

Zentrum für Europäische Wirtschaftsforschung $\mathrm{GmbH}$

Centre for European Economic Research 
Discussion Paper No. 08-038

\title{
Déjà Vu? \\ Short-Term Training in Germany 1980-1992 and 2000-2003
}

\author{
Bernd Fitzenberger, Olga Orlyanskaya, \\ Aderonke Osikominu, and Marie Waller
}

Download this ZEW Discussion Paper from our ftp server:

ftp://ftp.zew.de/pub/zew-docs/dp/dp08038.pdf

Die Discussion Papers dienen einer möglichst schnellen Verbreitung von neueren Forschungsarbeiten des ZEW. Die Beiträge liegen in alleiniger Verantwortung der Autoren und stellen nicht notwendigerweise die Meinung des ZEW dar.

Discussion Papers are intended to make results of ZEW research promptly available to other economists in order to encourage discussion and suggestions for revisions. The authors are solely responsible for the contents which do not necessarily represent the opinion of the ZEW. 


\section{Das Wichtigste in Kürze}

In den letzten Jahren hat die aktive Arbeitsmarktpolitik (AAMP) einen größeren Akzent auf Unterstützung bei der Arbeitssuche, Kontrolle und Überprüfung der Arbeitsverfügbarkeit sowie auf begrenzte Qualifizierung für eine kurzfristige Aktivierung der Arbeitslosen gesetzt. In Deutschland spiegelt sich die Fokussierung auf Aktivierungsstrategien in der Abkehr von traditionellen längeren Weiterbildungsmaßnahmen wider, die typischerweise einige Monate bis zwei Jahre dauern, hin zu kurzen Trainingsmaßnahmen mit einer Dauer von zwei bis zwölf Wochen. Heutige Kurzzeitmaßnahmen in Deutschland verfolgen zwei Hauptziele. Zum einen sollen sie die Wiedereingliederung der Teilnehmer in Beschäftigung durch Beratung und Qualifizierung (wie z.B. Bewerbungstraining, Beratung über Möglichkeiten der Arbeitsplatzsuche oder Vermittlung von elementaren Computerkenntnissen) erhöhen. Das zweite Ziel der Kurzzeitmaßnahmen ist die Feststellung der Aussichten des Arbeitssuchenden am Arbeitsmarkt sowie seiner Eignung für verschiedene berufliche Tätigkeiten, aber auch seiner Arbeitsverfügbarkeit und -bereitschaft.

Bereits in den 1980ern und Anfang der 1990er Jahre gab es in Deutschland Kurzzeitmaßnahmen nach §41a AFG, die den modernen Trainingsmaßnahmen sehr ähnlich waren. Während Aktivierung und Kontrolle ein wichtiges Ziel der aktuellen Trainingsmaßnahmen darstellen, konzentrierten sich die früheren Kurzzeitmaßnahmen lediglich auf Unterstützung bei der Arbeitssuche, begrenzte Kenntnisvermittlung und Beratung hinsichtlich zukünftiger Teilnahme an den längeren Weiterbildungsmaßnahmen.

Diese Arbeit schätzt Effekte von Kurzzeitmaßnahmen in Westdeutschland, die in den Zeitspannen 1980 bis 1992 und 2000 bis 2003 begonnen wurden, im Hinblick auf zwei Größen: Beschäftigung und Teilnahme an längeren Maßnahmen. Als erste Studie betrachtet die vorliegende Arbeit unter Verwendung von administrativen Daten gleichzeitig einen Zeitraum von achtzehn Jahren in den 1980ern und 1990ern und vier Jahren in den 2000er Jahren, um mittel- und langfristige Beschäftigungseffekte von Kurzzeitmaßnahmen zu untersuchen. Weiterhin ist dies die erste Arbeit, die die Kurzzeitmaßnahmen in den 1980ern und Anfang der 1990er Jahre mit modernen Evaluationsmethoden analysiert. Wir untersuchen die Wirksamkeit der verschiedenen Typen von Kurzzeitmaßnahmen. Da bei den früheren Kurzzeitmaßnahmen keine Überprüfung und Kontrolle der Arbeitslosen vorgesehen war, unterscheiden wir zwei Typen von Trainingsmaßnahmen in den 2000er Jahren: eine Trainingsvariante mit dem Schwerpunkt Kenntnisvermittlung und eine Kontrollvariante mit Schwerpunkt Überprüfung und Kontrolle der Suchanstrengungen. Nach unserer 
Einschätzung weisen die Kurzzeitmaßnahmen in den 1980er und 1990er Jahren eine größere Ähnlichkeit mit der Trainingsvariante der aktuellen Trainingsmaßnahmen auf.

Unsere Ergebnisse zeigen, dass die Kurzzeitmaßnahmen meistens längerfristige positive (oft signifikante) Beschäftigungseffekte aufweisen. Die Effekte sind besonders stark, wenn die Teilnahme zwischen dem siebten und zwölften Monat der Arbeitslosigkeitsperiode beginnt. Kleinere Effekte ergeben sich für die Kurzzeitmaßnahmen, die während des zweiten Jahres der Arbeitslosigkeitsperiode beginnen. Kurzzeitmaßnahmen mit einem Fokus auf Prüfung und Kontrolle der Suchanstrengungen zeigen etwas kleinere Effekte im Vergleich zur reinen Trainingsvariante. Die Lock-in-Periode war in den 1980er und 1990er Jahren länger im Vergleich zu den frühen 2000er Jahren. Kurzzeitmaßnahmen führen zu einer höheren Teilnahme an längeren Maßnahmen, wobei dieser Effekt in der früheren Zeitperiode viel stärker ausgeprägt war. Die Beschäftigungseffekte von früheren Kurzzeitmaßnahmen weisen keine signifikanten Unterschiede in der Periode zwischen 1980 und 1992 auf, d.h. es gibt keinen Beleg für Konjunktureffekte.

Die Tatsache, dass in einigen Fällen langfristige Effekte von Kurzzeitmaßnahmen geschätzt werden, überrascht vielleicht angesichts der kurzen Dauer der Maßnahmen. Diese Maßnahmen stellen keine beträchtliche Humankapitalinvestition dar. Zukünftige Untersuchungen sollten die Hypothese überprüfen, ob positive langfristige Maßnahmeeffekte auf eine höhere Teilnahmequote an längeren Maßnahmen zurückgeführt werden können. 


\section{Nontechnical Summary}

Over the past few years, active labor market policies (ALMP) have placed a greater emphasis on job search assistance, monitoring and testing work availability, as well as limited training to activate the unemployed in the short run. In Germany, the focus on activation strategies is reflected in the recent shift away from traditional longer further training programs, typically lasting a couple of months up to two years, to short-term training programs lasting between two and twelve weeks. Current shortterm training programs in Germany have two main goals. First, they are supposed to enhance reintegration of the participants into employment through guidance and qualification (like job-application training, general counseling on job search methods or limited computer skills). The second aim of short-term training is to assess the job seekers' labor market opportunities and their suitability for different jobs but also their availability and willingness to work.

Already in the 1980s and in the early 1990s, short-term training programs similar in nature to short-term training in the 2000s was in place in Germany. While activation and monitoring is a major goal of modern short-term training, the older short-term training focus solely on job search assistance, limited training, and guidance towards future participation in longer training programs.

This paper estimates the effects of short-term training programs in West Germany starting in the time period 1980 to 1992 and 2000 to 2003 regarding the two outcomes employment and participation in longer-term training programs. In particular, we contribute to the literature regarding the following three points: 1) Our paper is the first using administrative data covering such a long time period, namely 18 years in the 1980s and 1990s and four years in the early 2000s to study the mediumand long-term employment effects of short-term training. 2) This paper is the first to use state-of-the-art estimators of treatment effects for the short-term training programs in the 1980s and early 1990s. 3) We analyze the effectiveness of different types of short-term training. Because the older short-term training programs were not intended to test and monitor the unemployed, we distinguish two versions of short-term training in the 2000s, namely the training variant which focuses on skill provision and the checking variant which focuses on testing and monitoring search effort. We argue that the short-term training in the 1980s and 1990s are more similar to the training variant of modern short-term training.

Our results show that short-term training shows mostly persistently positive and often significant employment effects. The effects are particularly strong when participation starts during months 7 to 12 of the unemployment spell. We tend to find 
smaller effects for short-term training starting during the second year of the unemployment spell. Short-term training focusing on testing and monitoring search effort shows slightly smaller effects compared to the pure training variant. The lock-in periods lasted longer in the 1980s and 1990s compared to the early 2000s. Shortterm training results in higher future participation in longer training programs and this effect was much stronger for the earlier time period. The employment effects of the older short-term training programs did not change significantly by year between 1980 and 1992, i.e. there is no evidence for business cycle effects.

The fact that we find some long lasting effects of short-term training may be surprising given their short duration. These programs by themselves do not provide a sizeable human capital investment. Future research should investigate the hypothesis that the positive program effects can be traced back to the higher participation rates in longer training programs. 


\section{Déjà Vu? Short-Term Training in Germany 1980-1992 and $2000-2003^{1}$}

Bernd Fitzenberger, ${ }^{b}$ Olga Orlyanskaya, ${ }^{\natural}$ Aderonke Osikominu,, and MARIE WALLER ${ }^{\S}$

${ }^{b}$ Albert-Ludwigs-University Freiburg, ZEW, IZA, IFS, bernd.fitzenberger@vwl.uni-freiburg.de ${ }^{\natural}$ Albert-Ludwigs-University Freiburg, olga.orlyanskaya@vwl.uni-freiburg.de \#Albert-Ludwigs-University Freiburg, aderonke.osikominu@vwl.uni-freiburg.de

§Albert-Ludwigs-University Freiburg, CDSE Mannheim, marie.waller@vwl.uni-freiburg.de Correspondence:

Dept. of Economics, Albert-Ludwigs-University Freiburg, 79085 Freiburg, Germany

This version: June 2, 2008

Abstract: Short-term training has recently become the largest active labor market program in Germany regarding the number of participants. Little is known on the effectiveness of different types of short-term training and on their long-run effects. This paper estimates the effects of short-term training programs in West Germany starting in the time period 1980 to 1992 and 2000 to 2003 regarding the two outcomes employment and participation in longer training programs. We find that short-term training shows mostly persistently positive and often significant employment effects. Short-term training focusing on testing and monitoring search effort shows slightly smaller effects compared to the pure training variant. The lock-in periods lasted longer in the 1980s and 1990s compared to the early 2000s. Short-term training results in higher future participation in longer training programs and this effect was much stronger for the earlier time period.

Keywords: short-term training, employment effects, future training participation, administrative data, active labor market programs

JEL: C 14, J 68, H 43

\footnotetext{
${ }^{1}$ This study is part of the two projects "On the effectiveness of further training programs. An evaluation based on register data provided by the Institute for Employment Research, IAB" ("Über die Wirksamkeit von Fortbildungs- und Umschulungsmaßnahmen. Ein Evaluationsversuch mit prozessproduzierten Daten aus dem IAB"; IAB project number 6-531A) and "Employment effects of further training programs 2000-2002 - An evaluation based on register data provided by the Institute of Employment Research, IAB ("Die Beschäftigungswirkungen der FbW-Maßnahmen 2000-2002 auf individueller Ebene - Eine Evaluation auf Basis der prozessproduzierten Daten des IAB"; IAB project number 6-531.1A). These projects are joint with the Swiss Institute for International Economics and Applied Economic Research at the University of St. Gallen (SIAW) and the Institute for Employment Research (IAB). We gratefully acknowledge financial and material support by the IAB. We especially thank Stefan Bender for his efforts to make available the data on which this study is based. The usual caveat applies.
} 


\section{Contents}

1 Introduction $\quad 1$

2 Institutional Background $\quad 5$

3 Data $\quad 7$

3.1 Administrative Data Sets Used . . . . . . . . . . . . . . 7

3.2 Sample Selection . . . . . . . . . . . . . . . . . . . . 10

4 Evaluation Approach $\quad 11$

5 Empirical Results $\quad 15$

5.1 Estimation of the Propensity Scores . . . . . . . . . . . . . . . 15

5.2 Estimated Treatment Effects . . . . . . . . . . . . . . . . . 16

6 Conclusions $\quad 20$

$\begin{array}{lr}\text { Appendix } & 25\end{array}$ 


\section{Introduction}

"... there is almost never a stable set of active programmes to evaluate. Countries are continuously chopping and changing the mix of programmes."

Martin and Grubb (2001, p. 21)

Over the past few years, active labor market policies (ALMP) have placed a greater emphasis on job search assistance, monitoring and testing work availability, as well as limited training to activate the unemployed in the short run (OECD, 2007). There has been a greater focus to activate the unemployed to find unsubsidized jobs instead of placing unemployed in longer traditional training programs or public employment schemes. Short-term programs are replacing longer programs in order to prevent long lock-in effects.

Public sector sponsored training has traditionally been a main part of ALMP in many countries including Germany, see the surveys in Fay (1996), Martin and Grubb (2001), and Kluve (2006). Although there were many pessimistic assessments regarding the usefulness of such programs, these surveys point out that small scale training programs, which are well targeted to specific groups and which involve a strong on-the-job component, can show positive employment effects. Little is known in the literature on the medium- and long-run effects of activation strategies which combine training, job search assistance, and monitoring.

In Germany, the focus on activation strategies is reflected in the recent shift away from traditional longer further training programs, typically lasting a couple of months up to two years, to short-term training programs (Trainingsmaßnahmen, henceforth denoted by 'ST00' 三short-term training in the 2000s) lasting at most twelve weeks. In fact, ST00 have become the largest program in Germany regarding the number of participants with 1.07 Million individuals entering such a program in 2007 (Bundesagentur für Arbeit, 2007, pp. 54, 57). In contrast, only 356 thousand individuals entered longer further training programs in $2007 .^{2}$ Longer further training programs used to be the largest programs in Germany but have been replaced to a large extent by ST00. In light of the recent evidence that long training programs mostly show positive long-run employment effects (Fitzenberger et al., 2008; Lechner et al., 2004), one might be concerned that a focus on activation strategies comes at the expense of pushing the unemployed into instable jobs which do not result in permanently better employment prospects. There are different types of ST00

\footnotetext{
${ }^{2}$ In 2000 , there was a reverse ranking with 552 thousand individuals entering longer further training programs and 477 thousand individuals entering ST00 (see table 2 in the appendix).
} 
programs. In this paper, we distinguish programs which focus on skill provision and programs which focus on testing and monitoring search effort.

Between 1980 and 1992, short-term training programs similar in nature to ST00 were in place in West Germany (and since 1990 also in East Germany). These were the 'programs according to §41a Employment Promotion Act' (Maßnahmen nach $\S 41$ a Arbeitsförderungsgesetz, henceforth denoted by 'ST8092' $\equiv$ short-term training between 1980 and 1992). Due to budgetary reasons these programs were abolished in 1992. In 1998, short-term training in form of ST00 was reintroduced into the Social Code III (Sozialgesetzbuch III) that nowadays regulates labor market policy. While activation and monitoring is a major goal of ST00, the older ST8092 focus solely on job search assistance, limited training, and guidance towards future participation in longer training programs. Furthermore, the ST8092 programs were targeted to lowskilled and hard-to-place unemployed. The common features of the two programs are provision of short-term training, assessment of the unemployed (e.g. regarding future assignment to longer labor market programs), and job search assistance.

There have been a number of studies which evaluate effects of short-term training since 2000 (ST00) using different program evaluation estimators (Hujer et al., 2006; Lechner and Wunsch, 2007; Biewen et al., 2007; Stephan et al., 2006; Büttner, 2007; Osikominu, 2008). We are not aware of any study which uses modern approaches to estimate treatment effects for the older ST8092 programs. In the following, we summarize the evidence for ST00 and other short further training programs in West Germany. Lechner et al. (2004) analyze shorter further training programs in the 1990s that last longer than ST00 or ST8092 programs and provide more sizeable investments into professional skills. This study finds that the cumulated long-run employment effects of shorter training are higher than for longer training programs. Lechner and Wunsch (2006) show that the effect of longer training programs differs over the business cycle such that these programs show better employment effects when unemployment is high. This suggests that the activation effect of these programs on the unemployed is higher when unemployment is high. To our knowledge, no comparable evidence exists for short-term training, which has a stronger focus on activation compared to longer training programs.

Hujer et al. (2006) and Osikominu (2008) apply duration methods to evaluate ST00. They find evidence that ST00 reduce the duration of unemployment by increasing the hazard rate for exits from unemployment to employment in the short run. Osikominu (2008) finds no long-run effects on the hazard rate from employment back to unemployment. According to Hujer et al. (2006) men tend to benefit more strongly than women. Osikominu (2008), in contrast, does not find significant gen- 
der differences. Using different versions of matching estimators, Biewen et al. (2007) and Lechner and Wunsch (2007) show that for the time period of the early 2000s ST00 tends to perform better than longer further training programs regarding their employment effects. Biewen et al. (2007) find some significantly positive employment effects for ST00 in West Germany, whereas Lechner and Wunsch (2007) find no significantly positive treatment effects.

The studies reviewed so far do not distinguish different types of ST00. Stephan et al. (2006) consider participation in different versions of ST00 in the second half of the year 2002. The study uses a matching estimator and finds differing results depending on the type of ST00. The monitoring and testing version of ST00 does not show positive results, whereas the training versions show significantly positive or negative results depending upon whether the training takes place in a firm. Büttner (2007) uses a small experimental data set for 2005 in one region of West Germany and investigates the effect of sending an invitation to participate in a ST00 program which involves monitoring and testing. Out of 189 unemployed receiving an invitation 77 actually participate. The focus is on distinguishing the effects of announcement ('threat') of treatment from the effect of actual treatment. The study finds differences between the announcement effect and the treatment effect. In fact, the announcement results in earlier exits from unemployment, whereas the actual treatment shows no such effects. The exits from unemployment, however, do not translate into significantly higher exits to employment.

The literature review reveals that most studies did not distinguish different types of ST00 programs and that estimates of the long-run effects of short-term training are missing. This paper estimates the effects of short-term training programs in West Germany both for the time period 1980 to 1992 (ST8092) and 2000 to 2003 (ST00) regarding both employment and participation in longer-term training programs. This paper is the first to use state-of-the-art estimators of treatment effects for the short-term training programs in the 1980s and early 1990s. We investigate in particular whether there are lasting positive effects on employment outcomes and whether participation in these programs lead to higher participation in longer training programs afterwards. Furthermore, we analyze whether treatment effects differ over calendar time. We provide similar estimates for participation in shortterm training in the early 2000s. Because the ST8092 programs were not intended to test and monitor the unemployed, we distinguish two versions of ST00, namely the training variant which focuses on skill provision (QST00) and the checking variant which focuses on testing and monitoring search effort (MST00). We argue that the ST8092 programs are to be compared to the QST00 version of ST00. 
Methodologically, this paper follows Sianesi (2004) and estimates the effects of treatment starting after some given unemployment experience against the alternative of not starting treatment at this point of time and waiting longer. To be able to compare the results for the 1980s, 1990s, and early 2000s, we use the same methodological approach in all cases. Most evaluation studies in the past used a static approach evaluating the effects of receiving treatment during a certain period of time against the alternative of not receiving treatment during this period of time. ${ }^{3}$ In a dynamic setting, the timing of events becomes important, see Abbring and van den Berg (2003), Fredriksson and Johansson (2003), and Sianesi (2003, 2004). Static treatment evaluations implicitly condition on future outcomes leading to possibly biased treatment effects. The nontreated individuals in the data might be observed as nontreated because their treatment starts after the end of the observation period or because they exit unemployment before treatment starts (Fredriksson and Johansson, 2003).

Appropriate data for a long-term evaluation of public sector sponsored training programs were not available for a long time. This is the first paper using administrative data covering such a long time period, namely 18 years in the 1980s and 1990s and four years in the early 2000s to study the medium-term and, for the earlier time period, also the long-term employment effects of short-term training. The comparison between the earlier and the more recent time period is interesting because of the similarities between the two programs. In addition to employment, we also consider the effects on future participation in longer further training programs. This is important because one stated goal of short-term training in Germany is to assess the unemployed's need to participate in longer-term training programs. However, with an increasing focus on short-run activation strategies this goal may have lost in importance over time.

According to our results, short-term training shows mostly persistently positive and often significant employment effects. The effects are particularly strong when participation starts during months seven to twelve of the unemployment spell. The effects for short-term training starting during the second year of the unemployment spell tend to be smaller. The monitoring variant MST00 shows slightly smaller effects compared to the pure training variant QST00. The lock-in periods last longer for ST8092 compared to ST00 and the employment effects tend to be smaller for the earlier time period compared to QST00 but not compared to MST00. Short-term training results in higher future participation in longer further training programs and this effect is much stronger for the earlier time period.

\footnotetext{
${ }^{3}$ Hujer et al. (2006), Biewen et al. (2007), and Osikominu (2008) are exceptions.
} 
The remainder of this paper is structured as follows: Section 2 discusses the institutional aspects of short-term training in Germany. Section 3 focuses on the data used. Section 4 describes the methodological approach to estimate the treatment effects. The empirical results are discussed in section 5. Section 6 concludes. The appendix provides detailed empirical results.

\section{Institutional Background}

In Germany, training is traditionally a very important part of active labor market policy that aims at permanently reintegrating unemployed individuals into the labor market. ${ }^{4}$ Among the different types of training programs offered, medium- and longterm further training programs with a duration of up to two years used to play the most important role since their introduction in 1969. During the 1980s and since 1999, short-term training programs have been used at a large scale, too. Table 1 displays the entries into different types of active labor market programs in West Germany in the period 1979 to 1992 . It can be seen that entries into short-term training rose steadily until 1987, remained at a lower level in 1988 and 1989 and peaked again in 1990. Table 2 shows the participation numbers in Germany as well as West Germany for the more recent period since 1999. During the recent years participation in short-term training rose considerably. Since 2001, short-term training has become the most important type of training regarding the number of participants.

Modern short-term training programs (ST00) have two main goals. First, they are supposed to enhance reintegration of the participants into employment through guidance and qualification. This may comprise training job search skills through activities such as job-application training, simulation of job interviews or general counseling on job search methods. It may also involve the provision of specific skills (like limited computer skills or some technical tasks) that are necessary to improve the job seeker's labor market prospects. ${ }^{5}$ The second aim of short-term training is to assess the job seekers' labor market opportunities and their suitability for different jobs but also their availability and willingness to work. This may entail the preparation of detailed work plans to reintegrate the job seeker into the labor market, which can include participation in a longer training program. ${ }^{6}$ The

\footnotetext{
${ }^{4}$ Other important policy instruments are for instance employment subsidies, job creation in the public sector and measures to promote self-employment.

${ }^{5}$ For more details on the contents of short-term training see Kurtz (2003).

${ }^{6}$ One element of the law called Job-AQTIV Gesetz introduced in 2002 is to assess the job seeker
} 
availability of the unemployed is checked by pledging him or her to attend the fulltime training program. In our empirical analysis we therefore distinguish shortterm training programs for which the objective of qualifying the job seeker dominates from programs that put more emphasis on testing the availability to work and assessing the job seekers' opportunities using the information on the program codes in the data. Such a distinction can only be an approximation, as the same program can serve both purposes, even for the same participant. However, this distinction is also useful for the comparison with short-term training in the period 1980 to 1992 , where testing work availability was no (official) goal.

ST00 programs last between two and twelve weeks (with median duration around four weeks). Therefore, they are relatively cheap compared to the longer further training programs. In fact, a one-month short-term training course costs on average $€ 590$ per participant, whereas participation costs for a further training course lasting nine months amount to about $€ 5850$, see Biewen et al. (2007, table 1).

In the 1980s and 1990s, there existed short-term training programs (ST8092) that were very similar to those described above. The law governing active labor market policy at that time, the Employment Promotion Act (Arbeitsförderungsgesetz), included a paragraph on "measures to improve the employment chances for the unemployed" (Maßnahmen zur Verbesserung der Vermittlungsaussichten für Arbeitslose). The number of this paragraph gave the programs their name: 'measures according to $₫ 41 \mathrm{a}$ '. These programs where introduced in 1979 after the German labor market conditions had worsened in the 1970s and the number of long-term unemployed had risen considerably.

ST8092 programs were particularly targeted at individuals with lower reemployment chances as women, individuals without formal qualification and long-term unemployed. Hard-to-place and low-skilled individuals were under-represented in the existing medium- and long-term training programs. Short-term training was intended to counsel job seekers about their employment chances and the possibilities of participating in medium- or long-term training programs on the one hand and to teach limited skills helpful for either employment or participation in a longer training program on the other hand (Dobischat and Wassmann, 1981). Similar to ST00, ST8092 programs mostly consisted of full-time classroom training. The curriculum covered e.g. job counseling, information on public sponsored further training programs and on the general labor market situation, application and communication training, visiting firms and exercises with the intention to stabilize the personality

soon after becoming unemployed. This may be done through a short-term training program (Kurtz, 2003). 
of the participants. The maximal length was in general six weeks and there was no exam at the end of the course (Schneider, 1981).

At the end of 1992, ST8092 programs were abolished in order to reduce the costs of active labor market policy in a time of narrow budget. More intensive and completely sponsored short-term training programs only reappeared in 1997 (in the first years with a small number of participants only) and became important again from 1999 onwards (Kurtz, 2003).

When becoming unemployed individuals have to personally register at the local labor office. This involves a first counseling interview with the caseworker. Further interviews may follow from time to time. Based on these interviews in general the case workers decides whether to assign an unemployed to a program. Besides being registered as unemployed or as a job seeker at risk of becoming unemployed, candidates for short-term training do not have to fulfil any additional eligibility criteria. Depending on regional and local circumstances, caseworkers exercise a considerable amount of discretion when allocating unemployed to the different programs. Suitable programs are chosen from a pool of certified public or private providers.

The employment office pays all direct training costs for short-term training programs. In addition, ST00 participants continue to receive unemployment benefits or means-tested unemployment assistance, if they are eligible for such transfer payments. Thus, in the early 2000s, there exist no pure financial incentives for unemployed individuals to participate in ST00, in contrast to the situation in Germany before 1998. In the $1980 \mathrm{~s}$, short-term training was treated in the same way as longer further training programs. This means that participants who fulfilled certain eligibility criteria (mainly 720 days of employment subject to social security contributions within the last three years) received an income maintenance allowance which was more generous than the usual unemployment compensation. Those who where not eligible to receive income maintenance allowance continued to receive the means tested unemployment assistance (Bender et al., 2005).

\section{Data}

\subsection{Administrative Data Sets Used}

This study uses large administrative data sets for both time periods under investigation. For the 2000s, the empirical analysis is based on the so-called Integrated Em- 
ployment Biographies Sample (IEBS), a data set which has recently been made available by the Federal Employment Office of Germany. ${ }^{7}$ The IEBS consists of a $2.2 \%$ random sample of individual data drawn from the universe of data records collected in four different administrative processes: the Employment History (BeschäftigtenHistorik), the Benefit Recipient History (Leistungsempfänger-Historik), the Data on Job Search Originating from the Applicants Pool Database (Bewerberangebot), and the Participants-in-Measures Data (Maßnahme-Teilnehmer-Gesamtdatenbank). ${ }^{8}$

The Employment History is based on social insurance register data comprising employment information for employees subject to contributions to the public social security system. It covers the time period from 1990 to 2004. The main feature of these data is detailed daily information on the employment of each recorded individual. We use this information to account for the labor market history of individuals as well as to measure employment outcomes. For each employment spell, in addition to start and end dates, data from the Employment History contains information on personal as well as job and firm characteristics such as wage, industry, or occupation.

The Benefit Recipient History, the second data source, includes daily spells of unemployment benefit, unemployment assistance and income maintenance allowance payments individuals received between January 1990 and June 2005. The Benefit Recipient History provides information on the periods in which individuals were out of employment and therefore not covered by the Employment History. Moreover, we use additional information contained in the Benefit Recipients History involving sanctions and periods of exclusion from benefit receipt that may serve as indicators for a lack of motivation. Based on the information in the Employment and the Benefit Recipient History we calculate the individual entitlement periods to unemployment benefits. ${ }^{9}$

The third data source included in the IEBS is the so-called Data on Job Search Originating from the Applicants Pool Database, which contains rich information on individuals searching for jobs covering the period January 2000 to June 2005. The spells include detailed information concerning job search and personal characteristics, in particular on educational qualifications, nationality, and marital status.

\footnotetext{
${ }^{7}$ For detailed information on the IEBS see Hummel et al. (2005) and Bender, Biewen et al. (2005). Information in English can be found in Jacobebbinghaus and Seth (2007) or on the website of the Research Data Center (FDZ) of the German Federal Employment Office (http://fdz.iab.de/en.aspx).

${ }^{8}$ The data used here has been supplemented with some additional information that are not available in the standard version.

${ }^{9}$ For this purpose we rely on Plaßmann (2002) who summarizes the regulations regarding entitlements to unemployment benefits.
} 
They also provide information on whether the applicant wishes to change occupation, how many job proposals he or she already got, and about health problems that might influence employment chances. Finally, the data on applicants include regional and local identifiers, which we use to link regional and local information, for example unemployment rates at the district level.

The Participants-in-Measures Data, the fourth data source, contains detailed information on participation in public sector sponsored labor market programs covering the period January 2000 to June 2005. The data consist of spells indicating the start and end dates at a daily level, the type of the program as well as additional information. The Data Base of Program Participants allows us not only to identify participation in short-term training, but also in other programs such as employment subsidies. This is useful, as it enables us to distinguish between regular and subsidized employment when evaluating employment outcomes.

For the earlier time period covering the 1980s and 1990s, we use administrative individual data from three different sources. These data were assembled for the purpose of evaluating public sector sponsored training programs, see Bender, Bergemann et al. (2005) for a detailed description. The first data source is the IAB Employment Subsample (IAB Beschäftigtenstichprobe, IABS) of the Institute for Employment Research (IAB), see Bender et al. (2000) and Bender, Bergemann et al. (2005, chapter 2.1). The IABS is a $1 \%$ random sample of all employment records subject to social insurance contribution in the period 1975-1997. It also contains some information on periods of transfer payments from the unemployment insurance. The second data source is the the Benefit Payment Register (Leistungsempfängerdatei, LED) of the Federal Employment Office, see Bender, Bergemann et al. (2005, chapter 2.2). These data consist of spells on periods of transfer payments granted to unemployed and program participants in the period 1975-1997. They include very detailed information about income maintenance payments which allows to identify participation in different training programs, including the ST8092 programs investigated here. These benefit data contain more detailed information than the benefit data available in the IABS. The two data sources were merged to the so-called IABS-LED data set, see Bender, Bergemann et al. (2005) for details. Based on the IABS-LED data we calculate the individual entitlement periods to unemployment benefits.

As a third data source, we use an administrative survey on training participation, the so called FuU-data, see Bender, Bergemann et al. (2005, chapter 2.3). The Federal Employment Office collected these data for all participants in further training, retraining, and other training programs for internal monitoring and statistical 
purposes. For every participant, the FuU-data contain detailed information about the program and the participant.

The FuU-data were merged with the combined IABS-LED data by social insurance number and additional covariates. Numerous corrections were implemented in order to improve the quality of the data, see Bender, Bergemann et al. (2005, chapters 3-4) and Fitzenberger et al. (2008) for details. While the IABS provides information on personal characteristics and employment histories, the combination of the transfer payment data and the training participation data is used to identify the participation in different types of training programs.

\subsection{Sample Selection}

In this study, we analyze inflow samples into unemployment consisting of individuals living in West Germany who became unemployed after having been continuously employed for at least three months. The beginning of an unemployment spell is defined as the transition from regular (not marginal) employment to nonemployment and subsequently being in contact with the employment office (not necessarily immediately), either through benefit receipt, program participation or a job search spell. ${ }^{10}$ This way, we focus on individuals closely attached to the labor market, which allows to construct a control group that exhibits a similar employment history as the treated individuals. Furthermore, the beginning of unemployment defines a natural time scale to align treated and nontreated individuals. In order to exclude individuals in formal education or vocational training and individuals eligible for early retirement schemes, we only consider persons aged between 25 and 53 years at the beginning of their unemployment spell. Our evaluation focuses on participation in short-term training as the first training program that is attended over the course of an unemployment spell. Later participation in other active labor market programs is regarded as an outcome. Individuals in our control group may participate in another training program as a first program.

For the evaluation of ST00, we focus on an inflow sample into unemployment between the beginning of January 2000 and the end of June 2001. The analysis of ST8092 is based on an inflow sample into unemployment from January 1980 to January 1991. ${ }^{11}$ We consider participation in short-term training within the first two years of

\footnotetext{
${ }^{10}$ In the IEBS we can identify subsidized employment and thus exclude this from our definition of regular employment. This is unfortunately not possible for the 1980s and 1990s.

${ }^{11}$ This implies that the same individual may appear more than once in our evaluation sample. We take account of multiple inclusions of the same individual in the sample when calculating the
} 
an unemployment spell. Thus, we evaluate ST8092 programs starting from January 1980 until their abolishment in December 1992 and ST00 programs starting between January 2000 and June 2003. For the earlier time period, the data allow us to follow all individuals until the end of 1997. Therefore, we are able to estimate long-term effects of the ST8092 programs for all participants in our data. We follow the individuals in the more recent sample until the end of 2004.

In the sample covering the early 2000s, we distinguish two types of short-term training programs: the first one puts more emphasis on qualifying the job seeker (QST00), while the second one focuses on monitoring and testing the availability for work (MST00). We argue that the QST00 variant of ST00 is more similar to the ST8092 programs. For both time periods, we distinguish between treatment starting during months 0 to 6 of the unemployment spell (stratum 1), treatment starting during months 7 to 12 (stratum 2), and treatment starting during months 13 to 24 (stratum 3). We consider two outcome variables: the monthly employment status and participation in a longer-term training program later in the unemployment spell. The propensity scores and the treatment effects are estimated separately for the different program types, strata, and men and women. The number of participants and the size of the control group for each specification are depicted in table 3 in the appendix.

\section{Evaluation Approach}

Our goal is to analyze the effect of short-term training programs on two outcome variables, namely the individual monthly employment dummy and the individual participation in a longer-term training program. ${ }^{12}$ The treatment we evaluate is participating in a short-term training program as a first training program over the course of an unemployment spell against the alternative of not participating in a short-term training program as a first training program. This alternative includes the case of participating in a longer training program as first training program or no participation in any training program. We estimate the average treatment effect on the treated (ATT) of short-term training as first treatment against this alternative. Extending the static treatment approach to a dynamic setting, we follow Sianesi (2004) and apply the standard static treatment approach recursively

\footnotetext{
standard errors.

${ }^{12}$ The individual participation is measured as a dummy variable which is equal to one when the individual participates in a longer-term training program at some time in the future within the same unemployment spell.
} 
depending on the elapsed unemployment duration. The implementation builds upon the approach developed in Fitzenberger and Speckesser (2007), Biewen et al. (2007), and Fitzenberger et al. (2008).

Our empirical analysis is based upon the potential-outcome-approach to causality, see Roy (1951), Rubin (1974), and the survey of Heckman et al. (1999). Let the two potential outcomes be $\left\{Y^{0}, Y^{1}\right\}$, where $Y^{1}$ represents the outcome associated with participation in a short-term training program and $Y^{0}$ is the outcome when the individual does not participate in a short-term training program. For each individual, only one of the two potential outcomes is observed and the other outcome is counterfactual. We focus on the average treatment effect on the treated (ATT) of participating in a short-term training program against nonparticipation in a shortterm training program at some given elapsed unemployment duration (treatment versus waiting).

Fredriksson and Johansson (2003) argue that a static evaluation approach, which assigns unemployed individuals to a treatment group and a nontreatment group based on the treatment information observed in the data within a fixed time window, yields biased treatment effects. This is because the definition of the control group conditions on future outcomes or future treatment. For Sweden, Sianesi (2004) argues that all unemployed individuals are potential future participants in active labor market programs, a view which is particularly plausible for countries with comprehensive systems of active labor market policies (like Germany). In Germany, active labor market programs are implemented at a fairly large scale in international comparison. While unemployed, job seekers are continuously at risk of being assigned to an active labor market program. This discussion implies that a purely static evaluation of the different training programs is not warranted. Following Sianesi (2003, 2004), we analyze the effects of the first participation in a short-term training program during the unemployment spell considered conditional on the starting date of the treatment.

We analyze treatment conditional upon the unemployment spell lasting at least until the start of the treatment $k$ and this being the first treatment during the unemployment spell considered. Therefore, the ATT parameter (comparing treatments $k$ and l) of interest is

$$
\begin{gathered}
\theta(u, \tau)=E\left(Y^{1}(u, \tau) \mid T_{u}=1, U \geq u-1, T_{1}=\ldots=T_{u-1}=0\right) \\
-E\left(Y^{0}(u, \tau) \mid T_{u}=1, U \geq u-1, T_{1}=\ldots=T_{u-1}=0\right)
\end{gathered}
$$

where $T_{u}$ is the dummy variable indicating the start of treatment starting in month 
$u$ of the unemployment spell. $Y^{1}(u, \tau), Y^{0}(u, \tau)$ are the potential outcomes for treatments and nontreatment, respectively, in periods $u+\tau$, where treatment starts in period $u$ and $\tau=0,1,2, \ldots$, counts the months since the beginning of treatment. We compare treatment versus waiting (nonparticipation in the stratum). Note that the potential outcomes $Y^{1}(u, \tau), Y^{0}(u, \tau)$ differ by the month $u$ when treatment starts. The outcomes condition upon being unemployed at least until month $u$. Nonparticipation involves the possibility of treatment in a later stratum which implies that $Y^{0}(u, \tau)$ may correspond after while to a post treatment outcome.

The treatment parameter we actually estimate is the average within a stratum

$$
\theta(\tau)=\sum_{u} g_{u} \theta(u, \tau)
$$

where the average is taken with respect to the distribution $g_{u}$ of starting dates $u$ within the stratum.

Our estimated treatment parameter (1) mirrors the decision problem of the case worker and the unemployed who recurrently during the unemployment spell decide whether to start any of the programs now or to postpone participation to the future.

We evaluate the effects of treatment assuming the following dynamic version of the conditional mean independence assumption (DCIA)

$$
\begin{gathered}
E\left(Y^{0}(u, \tau) \mid T_{u}=1, U \geq u-1, T_{1}=\ldots=T_{u-1}=0, X\right) \\
=E\left(Y^{0}(u, \tau) \mid T_{\tilde{u}}=0 \text { for } u \leq \tilde{u} \leq \bar{u}, U \geq u-1, T_{1}=\ldots=T_{u-1}=0, X\right),
\end{gathered}
$$

where $X$ are observed characteristics that are time-invariant within an unemployment stratum and $\tau \geq 0$, see equation (1) above and the analogous discussion in Sianesi $\left(2004\right.$, p. 137). $T_{\tilde{u}}=0$ indicates nonparticipation between $u$ and $\bar{u}(\bar{u}$ is the end of the stratum of elapsed unemployment considered). We effectively assume that conditional on $X$, conditional on being unemployed at least until period $u-1$, and conditional on not receiving any treatment before the end of the stratum considered, $\bar{u}$, individuals are comparable in their nonparticipation outcome.

In our application, we apply propensity score matching building on Rosenbaum and Rubin's (1983) result on the balancing property of the propensity score in the case of a binary treatment. To account for the dynamic treatment assignment, we estimate the probability of treatment given that unemployment lasts long enough to make an individual 'eligible'. For treatment starting during months 1 to 6 (stratum 1 ), we take the total inflow sample of unemployed, and estimate a Probit model 
for treatment during stratum 1. The nonparticipation group includes those unemployed who either never participate in the treatment or who start a treatment after month 6. For treatment during strata 2 and 3, the basic sample consists of those unemployed who are still unemployed in the last month of the previous stratum. Implicitly, we assume that the actual beginning of treatment within a stratum is random conditional on $X$.

We implement a stratified local linear matching approach by imposing that the matching partners for a treated individual are still unemployed in the month before treatment starts, i.e. we exactly align treated and nontreated individuals by elapsed unemployment duration in months. In addition, we exactly align treated and controls by the calendar month in which the unemployment spell began. The expected counterfactual outcome for nonparticipation is obtained by means of a local linear regression on the propensity score. We use a crossvalidation procedure to obtain the bandwidth minimizing the squared prediction error for the average of the nonparticipation-outcome for the nearest neighbors of the treated individuals. ${ }^{13}$ An estimate for the variance of the estimated treatment effects is obtained through bootstrapping based on 250 resamples. We resample individuals. This way, we take account of the sampling variability in the estimated propensity score and we obtain standard errors which are clustered at the individual level.

As a balancing test, we use the regression test suggested in Smith and Todd (2005) to investigate whether the covariates are balanced sufficiently by matching on the estimated propensity score. For this purpose, each regressor in a given propensity score specification is regressed on a flexible polynomial of the predicted propensity score and interactions of this polynomial with the treatment dummy. We then determine the number of covariates in each specification for which the balancing test passes, i.e. the zero hypothesis that the polynomial of the propensity score interacted with the treatment dummy equals zero is not rejected. Furthermore, we investigate whether treated and matched nontreated individuals differ significantly in their outcomes before the beginning of the unemployment spell. We estimate these differences in the same way as the treatment effects after the beginning of the program. By construction, treated individuals and their matched counterparts exhibit the same unemployment duration until the beginning of treatment.

We also investigate effect heterogeneity of the ATT over calender time. For all treated individuals, we calculate the cumulated individual treatment effects by summing the individual monthly effects over the post-treatment time period. We then

\footnotetext{
${ }^{13}$ This method is an extension of the crossvalidation procedure suggested in Bergemann et al. (2008).
} 
run a linear regression of these individual effects on dummy variables for the different calendar years.

Finally, we need to discuss the plausibility of the DCIA (2) for our application. As Sianesi (2004), we argue that the participation probability depends upon the variables determining re employment prospects once unemployment begins. Consequently, all individuals are considered as matching partners who have left employment during the same time as the treated individuals (i.e. unemployment started in the same calendar month) and who have experienced the same elapsed unemployment duration before program participation. Furthermore, we included a rich set of individual characteristics and detailed information on previous employment experience in the propensity score estimation. E.g., we consider skill information, regional information, occupational status, industry as well as information on the remaining entitlement period to unemployment benefits. We use detailed information on past employment and unemployment spells to proxy for 'soft factors' that may influence participation such as the ability or motivation of the unemployed. As participation occurred at a fairly large scale, we argue further that assignment was not very targeted and driven by the regional supply of programs. Moreover, caseworkers had little guidance on 'what works for whom'. Supporting our point of view, Schneider et al. (2006) suggest that until the end of 2002 assignment to training was strongly driven by the supply of available courses. ${ }^{14}$

\section{$5 \quad$ Empirical Results}

\subsection{Estimation of the Propensity Scores}

We fitted the propensity scores separately for each of the 18 groups. In each case, we run an extensive specification search. The final specification was chosen based on economic considerations, statistical significance of the variables included, and the balancing tests described above. ${ }^{15}$ The final specifications include 15 to 31 covariates. The Smith and Todd (2005) balancing test is passed in almost all cases at a $1 \%$ significance level, except for one specification where we reject the null hypothesis

\footnotetext{
${ }^{14}$ For the evaluation of the employment effects of job creation schemes in 1999/2000 based on administrative data for Germany, Caliendo et al. (2004) were able to use a survey asking about the motivation of participants (such information is not available for our data). It turned out that both using administrative data and controlling for these motivational variables did not result in noticeably different estimated program effects compared to using administrative data only. This evidence also supports our point of view.

${ }^{15}$ Detailed estimation results are available in the additional appendix to this paper.
} 
for one regressor when using the quartic of the propensity score. Even regarding the $5 \%$ level we still pass 895 of 928 tests (both cubic and quartic regressions counted).

A closer look at the estimation results for the propensity scores reveals that the following information is particularly relevant: region, age, schooling degree, professional qualification, family status, children, foreign or German nationality, time spent in different labor market states during the last three years, remaining claim on unemployment benefits, industry of last employment, last occupation, last wage, reason for the end of last employment, year or quarter the person became unemployed in, health status, past health problems, information on whether a program was canceled within the last three years, penalties and disqualification from benefits within the last three years, participation in a program with a social work component, indication of lack of motivation within the last three years. ${ }^{16}$

\subsection{Estimated Treatment Effects}

The evaluation results for short-term training as first training program vs. waiting are shown in figures 1 to 3 . Each graph displays the average treatment effect on the treated (ATT), i.e. the difference between the actual and the counterfactual employment outcome averaged over those individuals who participate in the program under consideration. More precisely, we compare the actual employment outcome of the treated to the employment outcome these individuals would have had, had they not taken part in short-term training as a first training program in the respective time window of their unemployment spell. We distinguish between programs starting in three different time windows (strata) of elapsed unemployment: 0 to 6 months (stratum 1), 7 to 12 months (stratum 2), and 13 to 24 months (stratum 3). We evaluate treatment effects at different points in time. On the time axis in our graphs, positive values denote months since the program start, while negative values represent pre-unemployment months. We omit the period between the start of unemployment and the start of the program where both control and treatment group are unemployed. The dashed lines around the estimated ATT are bootstrapped 95 percent confidence bands. Treatment effects for a particular month are statistically significant if zero is not contained in the confidence band.

Figure 1 shows the estimated treatment effects for the short-term training programs

\footnotetext{
${ }^{16}$ The variables family status, reason for the end of last employment, health status, past health problems, penalties and disqualification from benefits within the last three years, participation in a program with a social work component, indication of lack of motivation within the last three years can not be generated in the older data. We instead hope to capture the information by using detailed variables on the individuals labor market history.
} 
in the early 2000s with a strong focus on qualification (QST00). The results for men are given in the left column, while those for women are shown in the right column. During the program and in the first time following the end of the program, participants typically have a lower monthly employment probability than they would have had if they had not participated in the program. This is the so-called lock-in effect. Figure 1 suggests relatively short (1 to 4 months) and not very pronounced lock-in effects. These lock-in effects are a bit deeper for stratum 1 (about 7 percentage points) than for the later strata (2 to 4 percentage points). After the short lock-in period, the difference between actual and counterfactual employment outcomes of participants turns positive. We find significant positive effects for men in the second and third stratum (i.e. those men who have been unemployed for at least half a year before entering a program) and for women in the first and second stratum, but not in the third stratum. However, the point estimates for the latter are positive after six months. The largest employment effects occur between month 12 and month 18. In the four groups with significant effects, the size of the effects reaches 9 to 17 percentage points. After 18 months, the effects tend to decline a little, but positive ATTs of 7 to 12 percentage points persist until the end of the observation period (18 to 36 months after program start depending on the stratum). These long lasting effects are quite remarkable given that the programs last only a few weeks. As we do not exclude participants who attend a second training program after short-term training, but regard the second program as an outcome, it could well be that the long-term effects are to some degree due to longer training programs which have been started as a result of the short-term training program. This would imply that short-term training serves as a bridge into a more intensive training programs and this combination eventually leads to positive employment effects.

Figure 2 presents the corresponding results for the short-term training programs in the early 2000s we classified as having a strong focus on testing the availability and willingness to work as well as the skills of job seekers (MST00). The graphs suggest that, while the point estimates of the monthly average treatment effects are mostly positive, they generally fail to be clearly significant. The only exception are women who receive treatment in months 7 to 12 (stratum 2) of their unemployment spell. After a small and very short lock-in-effect, we first observe a small and insignificant positive effect. Rising steadily over more than two years, it turns significant after 9 months and eventually reaches 16 percentage points. This picture fits into the scenario that part of the participants attend a second program as a result of the MST00 program and this combination of programs eventually may lead to positive employment effects. The trend of the treatment effect is similar for men and women in stratum 1, but in these cases the level is much lower and the effect is insignificant. 
The lock-in-effects show a similar picture for MST00 as for QST00. In sum, participants of MST00 seem to have benefited less from their program than participants of QST00 from the program they were assigned to.

Results for short-term programs in the period 1980-1992 (ST8092) are given in figure 3. The estimated monthly average treatment effects are positive after an initial lock-in-effect. Remarkably, the lock-in-period is typically longer for ST8092 than for ST00. Also, the monthly ATTs of ST8092 are mostly smaller than those of QST00 and statistically insignificant. Only for women unemployed for more than one year (stratum 3), the results show significantly positive treatment effects of 7 to 10 percentage points between month 6 and month 20 after program start. For the other groups the effects are - although for the time after the lock-in-period always positive - insignificant. Interestingly, for most groups the employment effect increases between month 18 and month 26 after treatment start. As discussed before, this is likely due to participation in another training program as a result of participation in short-term training. In sum, ST8092 programs were less successful in bringing people back to employment compared to ST00, in particular to QST00.

Table 5 shows averages of the monthly ATT's from month 6 after program start until the end of the observation period as a way of condensing employment effects after the end of the lock-in-period. In four cases for QST00 and two cases for MST00, the figures reported in table 5 suggest highly significant employment effects between 6 and 14 percentage points, for the other groups the effects are smaller and not (or only slightly) significant. The results for the ST8092 programs suggest significantly positive ATTs for women in stratum 2 and 3 and for men in stratum 2 in the range 6.2 to 7.4 percentage points despite the mostly insignificant point estimates in figure 3. The effects for the three other cases are smaller in size and not significant.

Table 4 shows gains and losses in months employed cumulated over up to two years (four years for the ST8092 programs, respectively) after program start as a way of condensing the graphical results in figures 1 to 3 . This measures by how much a participation in short-term training increases the time spent in employment in a given time period, when initial negative and subsequent positive employment effects are weighed against each other. While the gains are very small or not even positive over the first 6 months, they increase for most groups over a longer period. The positive employment effects of QST00 are confirmed again. The effects of QST00 cumulated over 24 months are in general larger than those of MST00 and ST8092. In the cases where we find significant effects after 24 months, these lie in a range between one and two and a half months. For example, men and women participating in QST00 after having been unemployed between 7 and 12 months (stratum 2) 
gain 2.4 months in employment during the first 24 months after the program start. Women participating in MST00 in stratum 2 gain 2.6 months in employment in two years. For the ST8092 programs, there are surprisingly high gains for women who were long-term unemployed before the program. After 48 months, we find significantly positive cumulated employment effects of ST8092 programs (in one case significance is given only at the $10 \%$ level) for women in stratum 2 and 3 and for men in stratum 2 .

Next, table 6 reports the estimated treatment effects on the participation rates. This means that instead of the employment effect we estimate the average effect of the short-term training program on the probability to participate in a longerterm further training program at least once during the remaining unemployment spell after the start of the short-term training program. All effects are positive and, with the exception of QST00 in stratum 2, they are all significant. Incidently, the employment effects for QST00 in stratum 2 are the highest among all QST00 cases while the participation effects are the lowest. In most cases, the participation effects are higher for women than for men and the effects are mostly higher for the ST8092 programs compared to short-term training in the 2000s. Furthermore, the effects are much higher for MST00 compared to QST00. This is in line with what one would expect: an important goal of MST00 is to define a path back into employment, including for some job seekers participation in a more intensive training program. A limited skill upgrade to directly enhance placement is a strong focus of QST00, as a result future program participation is a bit less of an issue. For the ST8092 programs, guiding needy job seekers into a long-term training program was an official goal. The estimated effects of participation rates reflect this goal, in particular for female participants who show an 18 to 25 percentage points higher probability to participate in a longer training program.

This study investigates program effects of ST8092 programs over 13 calendar years. Given this very long period, one could suspect that the employment effects differ over calendar time. Possibly, the activation effect of such programs is higher for the hard-to-place when unemployment is low or the programs give the unemployed an additional edge when unemployment is high. In order to investigate this type of potential effect heterogeneity, we regress the average individual treatment effects after the lock-in-period (summarized in table 5) on an intercept, year dummies, and the individual elapsed unemployment duration to investigate whether the effects differ between years. Bootstrap standard errors are calculated based on the resamples which are also used to bootstrap the standard errors of the effect estimates. According to the results of these regressions, the ATTs do not differ over 
time: a chi-square test for joint significance of the year dummies does not suggest any effect heterogeneity (see table 7). Thus, there is no evidence for the business cycle affecting the employment effects of short-term training, a finding which is in contrast to the results for longer training programs in Lechner and Wunsch (2006).

\section{Conclusions}

Recently, there has been a greater emphasis on job search assistance, monitoring and testing work availability, as well as limited training to activate the unemployed (OECD 2007). In Germany, the focus on activation strategies is reflected in the recent shift away from traditional longer further training programs typically lasting a couple of months up to 2 years to short-term training programs (ST00) lasting at most 12 weeks. In fact, ST00 have become the largest program in Germany regarding the number of participants with 1.07 Million individuals entering such a program in 2007 (Bundesagentur für Arbeit, 2007, pp. 54, 57). Between 1980 and 1992, a similar large scale short-term training program was in place in Germany. These were the 'programs according to §41a Employment Promotion Act' (ST8092).

This paper estimates the effects of short-term training programs in West Germany both for the time period 1980 to 1992 and 2000 to 2003 regarding both future employment and future participation in longer training programs. This is the first paper to analyze these programs for the earlier time period and to estimate longrun effects on outcomes. Our results show that short-term training shows mostly persistently positive and often significant employment effects. The effects are particularly strong when participation starts during months 7 to 12 of the unemployment spell. We tend to find smaller effects for short-term training starting during the second year of the unemployment spell. When short-term training focuses on testing and monitoring search effort, there are slightly smaller effects compared to when the focus is on training only. The lock-in periods lasted longer in the 1980s and 1990s compared to the early 2000s. Short-term training results in higher future participation in longer training programs and this effect was much stronger for the earlier time period. The employment effects of the ST8092 programs did not change significantly by year between 1980 and 1992, i.e. there is no evidence for business cycle effects in contrast to the results for longer training programs in Lechner and Wunsch (2006).

Our findings most likely reflect a change in active labor market policy between 1992 and 2000. In the 2000s, there is a strong focus on activating the unemployed. In 
contrast, in the 1980s and 1990s it was accepted policy to 'give the unemployed some time' and to encourage them to participate in longer training programs when this seemed advisable and the unemployed were hard to place. Our results suggest that the policy reorientation towards activation did not result in worse employment outcomes. If anything, as far as comparable, ST00 programs with a focus on training show better employment effects. As a caveat, we have to acknowledge, however, that the estimated treatment effects for the two time periods are obtained for different selective treatment samples, i.e. the effects can not be compared without accounting for these differences.

The fact that we find some long lasting effects of short-term training may be surprising given their short duration. These programs by themselves do not provide a sizeable human capital investment. Future research should investigate the hypothesis that the positive program effects can be traced back to the higher participation rates in longer training programs. However, as one piece of evidence against this hypothesis, we find that in the two cases with no significant participation effects the employment effects of ST00 are particularly high. However, a thorough investigation of the hypothesis would require an evaluation approach for multiple sequential treatments as e.g. the one developed by Lechner (2004), but it remains an open question whether the stringent identifying assumptions required are satisfied in applications like ours. As a final caveat, an overall assessment of the microeconomic effects of short-term training is not possible, because the necessary information for a comprehensive cost-benefit-analysis is lacking in our data.

\section{References}

Abbring, J. and G.J. van den Berg (2003). "The Nonparametric Identification of Treatment Effects in Duration Models." Econometrica 71, 1491-1517.

Bender, S., A. Haas, and C. Klose (2000). "IAB employment subsample 19751995." Schmollers Jahrbuch (Journal of Applied Social Science Studies) 120, 649-662.

Bender, S., M. Biewen, B. Fitzenberger, M. Lechner, R. Miquel, A. Osikominu, M. Waller, C. Wunsch (2005). "Die Beschäftigungswirkung der FbW-Maßnahmen 2000 - 2002 auf individueller Ebene: Eine Evaluation auf Basis der prozessproduzierten Daten des IAB - Zwischenbericht Oktober 2005." Goethe University Frankfurt and SIAW St. Gallen. 
Bender, S., A. Bergemann, B. Fitzenberger, M. Lechner, R. Miquel, S. Speckesser, C. Wunsch (2005). "Über die Wirksamkeit von Fortbildungs- und Umschulungsmaßnahmen." Beiträge zur Arbeitsmarkt- und Berufsforschung 289, IAB, Nürnberg.

Bergemann, A. B. Fitzenberger, and S. Speckesser (2008). "Evaluating the Dynamic Employment Effects of Training Programs in East Germany Using Conditional Difference-in-Differences." Journal of Applied Econometrics $<$ forthcoming $>$.

Biewen, M., B. Fitzenberger, A. Osikominu, and M. Waller (2007). "Which Program for Whom? Evidence on the Comparative Effectiveness of Public Sponsored Training Programs in Germany." IZA Discussion Paper, No. 2885, Bonn.

Büttner, T. (2007). "Ankündigungseffekt oder Maßnahmewirkung? Eine Evaluation von Trainingsmaßnahmen zur Überprüfung der Verfügbarkeit." IAB Discussion Paper, 25/2007, Nürnberg.

Bundesanstalt für Arbeit (1980-1993). "Förderung der beruflichen Bildung/Weiterbildung." Nürnberg (various issues).

Bundeanstalt für Arbeit (1985, 1994). "Amtliche Nachrichten der Bundesanstalt für Arbeit." Nürnberg (various issues).

Bundeagentur für Arbeit (2000-2004). "Arbeitsmarkt." Nürnberg (various issues).

Bundeagentur für Arbeit (2007). "Der Arbeits- und Ausbildungsmarkt in Deutschland - Dezember und das Jahr 2007." Monthly Report, Nürnberg.

Caliendo, M., R. Hujer, S.L. Thomsen, and C. Zeiss (2004). "Einfluss von motivationalen Merkmalen aus Befragungsdaten auf die Schätzung des Beschäftigungseffektes von ABM-Maßnahmen." Unpublished Manuscript, Goethe University Frankfurt.

Dobischat, R. and H. Wassmann (1981). "Die Teilnahme der Arbeitslosen an Maßnahmen zur Verbesserung der Vermittlungsaussichten und ihre Nutzung für die berufliche Weiterbildung." Berufsbildung in Wissenschaft und Praxis 6/81, $17-19$.

Fay, R. (1996). "Enhancing the Effectiveness of Active Labour Market Policies: Evidence from Programme Evaluations in OECD countries." Labour Market and Social Policy Occasional Papers, 18, OECD, Paris. 
Fitzenberger, B., A. Osikominu, and R. Völter (2008). "Get Training or Wait? Long-Run Employment Effects of Training Programs for the Unemployed in West Germany." Annales d'Economie et de Statistique < forthcoming $>$.

Fredriksson, P. and P. Johansson (2003). "Program Evaluation and Random Program Starts." Institute for Labour Market Policy Evaluation (IFAU), Uppsala, Working Paper, 2003:1.

Heckman, J. R.J. LaLonde, and J.A. Smith (1999). "The Economics and Econometrics of Active Labor Market Programs." In: O. Ashenfelter and D. Card (eds.), Handbook of Labor Economics, Vol. 3 A, Amsterdam: Elsevier Science, 1865-2097.

Hujer, R., S.L. Thomsen, and C. Zeiss (2006). "The Effects of Short-Term Training Measures on the Individual Unemployment Duration in West Germany." Discussion Paper 06-065, ZEW Mannheim.

Hummel, E., P. Jacobebbinghaus, A. Kohlmann, M. Oertel, C. Wübbeke, and M. Ziegerer (2005). "Stichprobe der Integrierten Erwerbsbiographien, IEBS 1.0." FDZ Datenreport 6/2005, Nürnberg.

Jacobebbinghaus, P. and S. Seth (2007). "The German Integrated Employment Biographies Sample IEBS." Journal of Applied Social Science Studies (Schmollers Jahrbuch) 127, 335-342.

Kluve, J. (2006). "The Effectiveness of European Active Labor Market Policy." Discussion Paper, RWI Essen.

Kurtz, B. (2003) "Trainingsmaßnahmen - Was verbirgt sich dahinter?" IAB Werkstattbericht No. 8, Nürnberg.

Lechner, M. (2004). "Sequential Matching Estimation of Dynamic Causal Models." Discussion Paper 2004-06, University of St. Gallen.

Lechner, M., R. Miquel, and C. Wunsch (2004). "Long-Run Effects of Public Sector Sponsored Training in West Germany." IZA Discussion Paper No. 1443.

Lechner, M. and C. Wunsch (2006). "Are Training Programs more effective when Unemployment is high?" IZA Discussion Paper No. 2355.

Lechner, M. and C. Wunsch (2007). "What Did All the Money Do? On the General Ineffectiveness of Recent West German Labour Market Programmes." IZA Discussion Paper No. 2800. 
Martin, J.P. and Grubb, D. (2001). "What works and for whom: A review of OECD countries' experiences with active labour market policies." Swedish Economic Policy Review 8, 9-56.

Osikominu, A. (2008). "Is Short Training Short-Lived and Long Training LongLasting? A Multi-State Duration Analysis of the Dynamic Effects of Training Schemes For the Unemployed." Discussion Paper, mimeo, Albert-LudwigsUniversity-Freiburg.

OECD (2007). "Activating the Unemployed: What Countries do?" Employment Outlook, Chapter 5, Paris.

Plaßmann, G. (2002). "Der Einfluss der Arbeitslosenversicherung auf die Arbeitslosigkeit in Deutschland." Beiträge zur Arbeitsmarkt- und Berufsforschung, BeitrAB 255.

Rosenbaum, P.R. and D.B. Rubin (1983). "The Central Role of the Propensity Score in Observational Studies for Causal Effects." Biometrika 70, 41-55.

Roy, A.D. (1951). "Some Thoughts on the Distribution of Earnings." Oxford Economic Papers 3, 135-146.

Rubin, D.B. (1974). "Estimating Causal Effects of Treatments in Randomized and Nonrandomized Studies." Journal of Educational Psychology 66, 688-701.

Schneider, H. (1981). "Erfahrungen mit "41a"." Arbeit und Beruf 4/1981, 97-99.

Schneider, H., K. Brenke, D. Hess, L. Kaiser, J. Steinwede und A. Uhlendorff (2006). "Evaluation der Maßnahmen zur Umsetzung der Vorschläge der HartzKommission - Modul 1b: Förderung beruflicher Weiterbildung und Transferleistungen." IZA Research Report, No. 7, Bonn.

Sianesi, B. (2003). "Differential Effects of Swedish Active Labour Market Programs for Unemployed Adults in the 1990s." Discussion Paper, Institute for Fiscal Studies, London.

Sianesi, B. (2004). "An Evaluation of the Swedish System of Active Labor Market Programs in the 1990s." Review of Economics and Statistics 86, 133-155.

Smith, J.A. and P. Todd (2005). "Rejoinder." Journal of Econometrics 125, 365375 .

Stephan, G. S. Rässler, and T. Schewe (2006). "Das TrEffeR-Projekt der Bundesagentur für Arbeit - die Wirkung von Maßnahmen aktiver Arbeitsmarktpolitik." Zeitschrift für ArbeitsmarktForschung, 39(3/4), 447-465. 


\section{Appendix}

Table 1: Entries into Active Labor Market Programs in West Germany from 19791992 (in Thousand)

\begin{tabular}{l|ccccc}
\hline & 1979 & 1980 & 1981 & 1982 & 1983 \\
\hline Training programs & 209 & 247 & 280 & 266 & 306 \\
- further training & 149 & 162 & 190 & 189 & 220 \\
- short-term training & 0.7 & 14 & 25 & 23 & 24 \\
- retraining & 31 & 38 & 47 & 42 & 42 \\
- job training & 29 & 33 & 17 & 11 & 20 \\
Job creation schemes & 20 & 15 & 14 & 8 & 23 \\
\hline & 1984 & 1985 & 1986 & 1987 & 1988 \\
\hline Training programs & 353 & 409 & 530 & 596 & 566 \\
- further training & 260 & 298 & 374 & 420 & 420 \\
- short-term training & 30 & 38 & 52 & 63 & 29 \\
- retraining & 43 & 45 & 59 & 65 & 66 \\
- job training & 19 & 28 & 45 & 49 & 51 \\
Job creation schemes & 26 & 34 & 41 & 42 & 38 \\
\hline & 1989 & 1990 & 1991 & 1992 & \\
\hline Training programs & 490 & 574 & 594 & 575 & \\
- further training & 361 & 383 & 421 & 418 & \\
- short-term training & 27 & 59 & 53 & 47 & \\
- retraining & 61 & 63 & 70 & 81 & \\
- job training & 41 & 68 & 49 & 29 & \\
Job creation schemes & 28 & 27 & 28 & 18 & \\
\hline So & & & & \\
\hline
\end{tabular}

Source: Bundesanstalt für Arbeit (1980-1993), Bundesanstalt für Arbeit $(1985,1994)$. 
Table 2: Entries into Active Labor Market Programs in Germany and West Germany from 1999-2004 (in Thousand)

\begin{tabular}{l|cccccc}
\hline & 1999 & 2000 & 2001 & 2002 & 2003 & 2004 \\
\hline Qualification programs & 1,108 & 1,221 & 1,069 & 1,537 & 1,502 & 1,548 \\
- further and retraining & 491 & 552 & 450 & 456 & 255 & 185 \\
- short-term training & 432 & 477 & 565 & 877 & 1,064 & 1,188 \\
Employment subsidies & 538 & 459 & 465 & 544 & 808 & 950 \\
Placement and advisory services & 532 & 601 & 742 & 934 & 2,920 & 5,134 \\
Job creation schemes & 353 & 314 & 246 & 220 & 194 & 170 \\
Specific measures for youths & 244 & 263 & 265 & 294 & 389 & 408 \\
Other & 312 & 391 & 516 & 457 & 212 & 309 \\
Total & 3,087 & 3,249 & 3,304 & 3,985 & 6,025 & 8,520 \\
\hline & & \multicolumn{5}{c}{ West Germany } \\
Qualification programs & 714 & 770 & 643 & 972 & 985 & 1,038 \\
- further and retraining & 307 & 338 & 261 & 273 & 161 & 124 \\
- short-term training & 265 & 286 & 339 & 545 & 690 & 789 \\
Employment subsidies & 245 & 225 & 206 & 245 & 365 & 481 \\
Placement and advisory services & 286 & 279 & 296 & 375 & 1,281 & 2,797 \\
Job creation schemes & 96 & 89 & 73 & 63 & 39 & 42 \\
Specific measures for youths & 181 & 193 & 191 & 210 & 262 & 270 \\
Other & 231 & 296 & 370 & 345 & 17 & 175 \\
Total & 1,753 & 1,852 & 1,778 & 2,210 & 2,949 & 4,803 \\
\hline Sorre: Bung
\end{tabular}

Source: Bundesagentur für Arbeit (2001, 2002, 2003, 2004, 2005). 
Table 3: Participation in short-term Training as a First Training Program for the Inflow Samples into Unemployment

\begin{tabular}{l|lll}
\hline Stratum & Months 1 to 6 & Months 7 to 12 & Months 13 to 24 \\
\hline \multicolumn{5}{|c}{ ST8092 } \\
\hline Male Participants & 165 & 201 & 183 \\
Male Control Group & $59921^{a}$ & $25674^{a}$ & 15631 \\
Female Participants & 145 & 145 & 167 \\
Female Control Group & $35782^{a}$ & 22970 & 17020 \\
\hline \multicolumn{4}{c}{ ST00 } \\
Male Participants QST00 & 559 & 221 & 211 \\
Male Participants MST00 & 531 & 177 & 214 \\
Male Control Group & 20979 & 8337 & 5122 \\
Female Participants QST00 & 537 & 214 & 130 \\
Female Participants MST00 & 325 & 126 & 115 \\
Female Control Group & 13848 & 7070 & 4975 \\
\hline
\end{tabular}

${ }^{a}$ For these three groups, we randomly selected half of the available non-participants due to computer constraints. 
Table 4: Cumulated Treatment Effects

\begin{tabular}{|c|c|c|c|}
\hline \multicolumn{4}{|c|}{ QST00, Men } \\
\hline & 6 months & 12 months & 24 months $^{a}$ \\
\hline Stratum 1 & $-0.145(0.090)$ & $-0.015(0.187)$ & $0.262(0.378)$ \\
\hline Stratum 2 & $0.274(0.139)^{* *}$ & $1.005(0.308)^{* * *}$ & $2.429(0.657)^{* * *}$ \\
\hline Stratum 3 & $0.319(0.108)^{* * *}$ & $0.799(0.241)^{* * *}$ & $1.518(0.409)^{* * *}$ \\
\hline \multicolumn{4}{|c|}{ QST00, Women } \\
\hline & 6 months & 12 months & 24 months $^{a}$ \\
\hline$\overline{\text { Stratum } 1}$ & $-0.080(0.083)$ & $0.369(0.191)^{*}$ & $1.197(0.422)^{* * *}$ \\
\hline Stratum 2 & $-0.009(0.139)$ & $0.669(0.313)^{* *}$ & $2.419(0.699)^{* * *}$ \\
\hline Stratum 3 & $-0.108(0.089)$ & $0.013(0.254)$ & $0.224(0.482)$ \\
\hline \multicolumn{4}{|c|}{ MST00, Men } \\
\hline & 6 months & 12 months & 24 months $^{a}$ \\
\hline Stratum 1 & $-0.142(0.089)$ & $-0.167(0.191)$ & $-0.175(0.403)$ \\
\hline Stratum 2 & $-0.029(0.115)$ & $0.142(0.277)$ & $0.378(0.560)$ \\
\hline Stratum 3 & $0.166(0.096)^{*}$ & $0.557(0.236)^{* *}$ & $0.984(0.393)^{* *}$ \\
\hline \multicolumn{4}{|c|}{ MST00, Women } \\
\hline & 6 months & 12 months & 24 months $^{a}$ \\
\hline Stratum 1 & $-0.203(0.102)^{* *}$ & $-0.322(0.230)$ & $-0.044(0.452)$ \\
\hline Stratum 2 & $0.223(0.162)$ & $0.907(0.404)^{* *}$ & $2.590(0.896)^{* * *}$ \\
\hline Stratum 3 & $0.038(0.107)$ & $0.265(0.277)$ & $0.533(0.498)$ \\
\hline
\end{tabular}

\begin{tabular}{l|llll}
\hline \multicolumn{5}{c}{ ST8092, Men } \\
\hline & 6 months & 12 months & 24 months & 48 months \\
\hline Stratum 1 & $-0.448(0.143)^{* * *}$ & $-0.343(0.315)$ & $-0.050(0.631)$ & $1.308(1.274)$ \\
Stratum 2 & $-0.285(0.118)^{* *}$ & $-0.004(0.300)$ & $0.910(0.627)$ & $2.336(1.168)^{* *}$ \\
Stratum 3 & $-0.042(0.116)$ & $0.161(0.258)$ & $0.522(0.552)$ & $1.271(1.236)$ \\
\hline
\end{tabular}

ST8092, Women

\begin{tabular}{l|llll}
\hline & 6 months & 12 months & 24 months & 48 months \\
\hline Stratum 1 & $-0.150(0.142)$ & $0.039(0.342)$ & $0.289(0.770)$ & $0.917(1.501)$ \\
Stratum 2 & $-0.302(0.154)^{*}$ & $0.019(0.389)$ & $0.910(0.844)$ & $2.813(1.595)^{*}$ \\
Stratum 3 & $0.130(0.104)$ & $0.613(0.245)^{* *}$ & $1.675(0.543)^{* * *}$ & $3.124(1.122)^{* * *}$ \\
\hline
\end{tabular}

${ }^{a}$ In stratum 3 the treatment effects are summed over 19 months.

Note: Sum of the monthly treatment effects from month zero (program start). ${ }^{* * *}=$ statistically significant at $1 \%,{ }^{* *}=$ at $5 \%,{ }^{*}=$ at $10 \%$, bootstrapped standard errors. 
Table 5: Average ATT after Lock-in-Period

\begin{tabular}{l|ll}
\hline & \multicolumn{1}{c}{ QST00 } \\
\hline Stratum 1 & $0.028(0.016)^{*}$ & Women \\
Stratum 2 & $0.111(0.031)^{* * *}$ & $0.070(0.020)^{* * *}$ \\
Stratum 3 & $0.092(0.026)^{* * *}$ & $0.025(0.032)$ \\
\hline \multicolumn{3}{|c}{ MST00 } \\
\hline \multicolumn{4}{c}{ Men } & Women \\
\hline Stratum 1 & $0.014(0.019)$ & $0.024(0.019)$ \\
Stratum 2 & $0.027(0.025)$ & $0.143(0.042)^{* * *}$ \\
Stratum 3 & $0.063(0.025)^{* *}$ & $0.038(0.032)$ \\
\hline \multicolumn{3}{c}{ ST8092 } \\
\hline Stratum 1 & Men & Women \\
Stratum 2 & $0.043(0.029)$ & $0.025(0.034)$ \\
Stratum 3 & $0.062(0.027)^{* *}$ & $0.074(0.036)^{* *}$ \\
\hline
\end{tabular}

Note: Average of the monthly treatment effects from month six since program start until the end of the observation period (until month 48 for ST8092 programs). ${ }^{* *}=$ statistically significant at $1 \%,{ }^{* *}=$ at $5 \%,{ }^{*}=$ at $10 \%$, bootstrapped standard errors.

Table 6: ATT for Participation Rates

\begin{tabular}{l|ll}
\hline \multicolumn{3}{|c}{ QST00 } \\
\hline & Men & Women \\
\hline Stratum 1 & $0.083(0.018)^{* * *}$ & $0.063(0.018)^{* * *}$ \\
Stratum 2 & $0.016(0.025)$ & $0.025(0.031)$ \\
Stratum 3 & $0.047(0.024)^{* *}$ & $0.106(0.036)^{* * *}$ \\
\hline \multicolumn{3}{|c}{ MST00 } \\
\hline \multicolumn{4}{|c}{} \\
\hline Stratum 1 & $0.164(0.020)^{* * *}$ & Women \\
Stratum 2 & $0.183(0.032)^{* * *}$ & $0.200(0.045)^{* * *}$ \\
Stratum 3 & $0.132(0.027)^{* * *}$ & $0.110(0.034)^{* * *}$ \\
\hline \multicolumn{3}{c}{ ST8092 } \\
\hline Stratum 1 & $0.092(0.033)^{* * *}$ & Women \\
Stratum 2 & $0.218(0.034)^{* * *}$ & $0.180(0.038)^{* * *}$ \\
Stratum 3 & $0.194(0.041)^{* * *}$ & $0.229(0.037)^{* * *}$ \\
\hline
\end{tabular}

Note: Treatment effects until the end of the observation period (until month 48 for ST8092 programs) ${ }^{* * *}=$ statistically significant at $1 \%,{ }^{* *}=$ at $5 \%,{ }^{*}=$ at $10 \%$, bootstrapped standard errors. 
Table 7: Test of Heterogeneity of Employment Effects over Time

\begin{tabular}{l|ll}
\hline & $\chi^{2}$-Statistic $(p$-Value $)$ \\
\hline & Men & Women \\
\hline Stratum 1 & $8.06(0.701)$ & $2.91(0.992)$ \\
Stratum 2 & $15.94(0.143)$ & $12.79(0.235)$ \\
Stratum 3 & $10.32(0.502)$ & $7.45(0.762)$ \\
\hline
\end{tabular}

Note: Test on joint significance of all year dummies in a regression of the individual treatment effects averaged over the months after program start (see table 5) on an intercept, year dummies, and elapsed unemployment duration. Empirical standard errors are calculated from bootstrap resamples. 
Figure 1: Average Treatment Effect on the Treated (ATT)
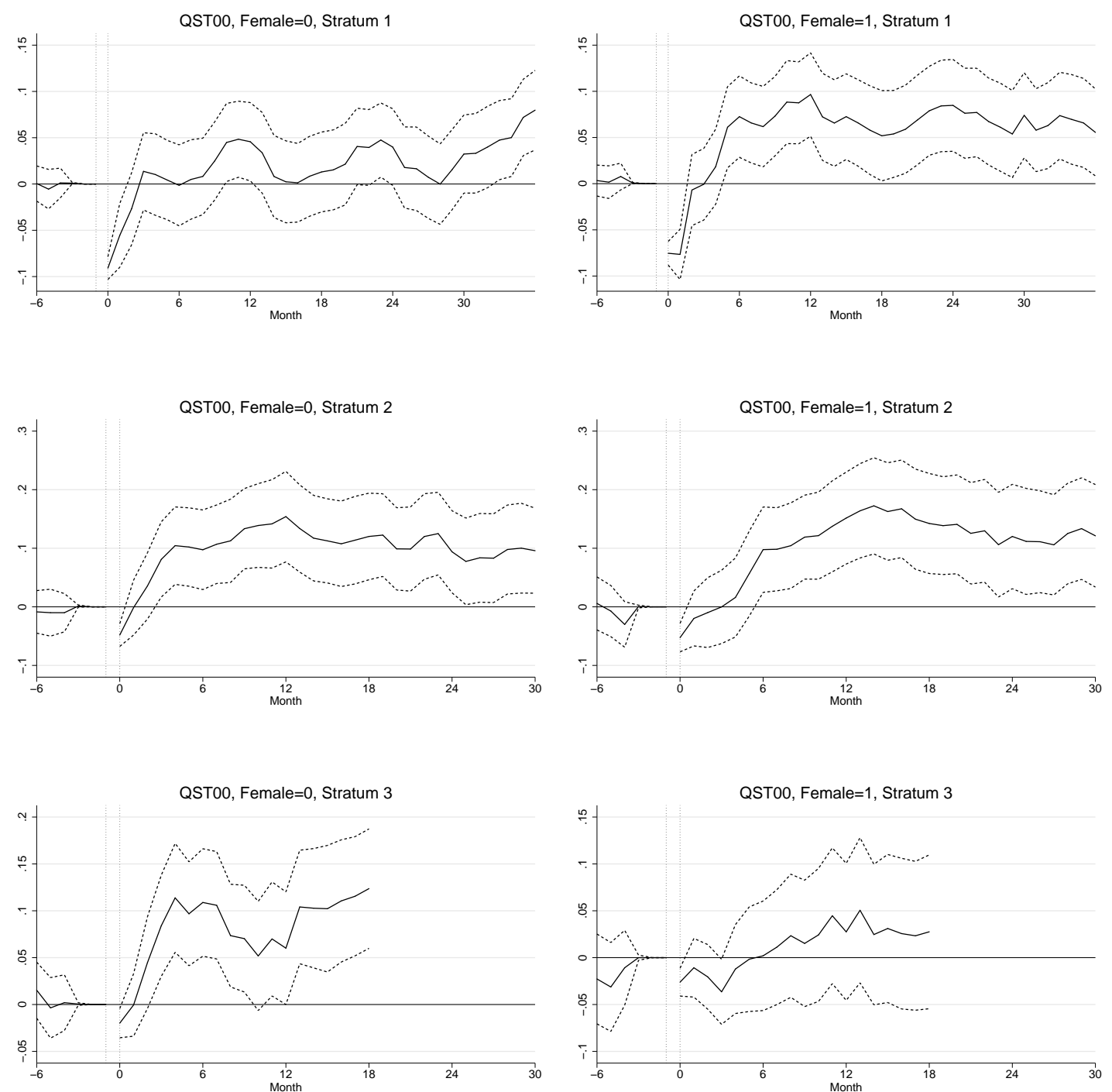

Difference in employment rates is measured on the ordinate, pre-unemployment $(<0)$ and posttreatment $(\geq 0)$ months on the abscissa. 
Figure 2: Average Treatment Effect on the Treated (ATT)
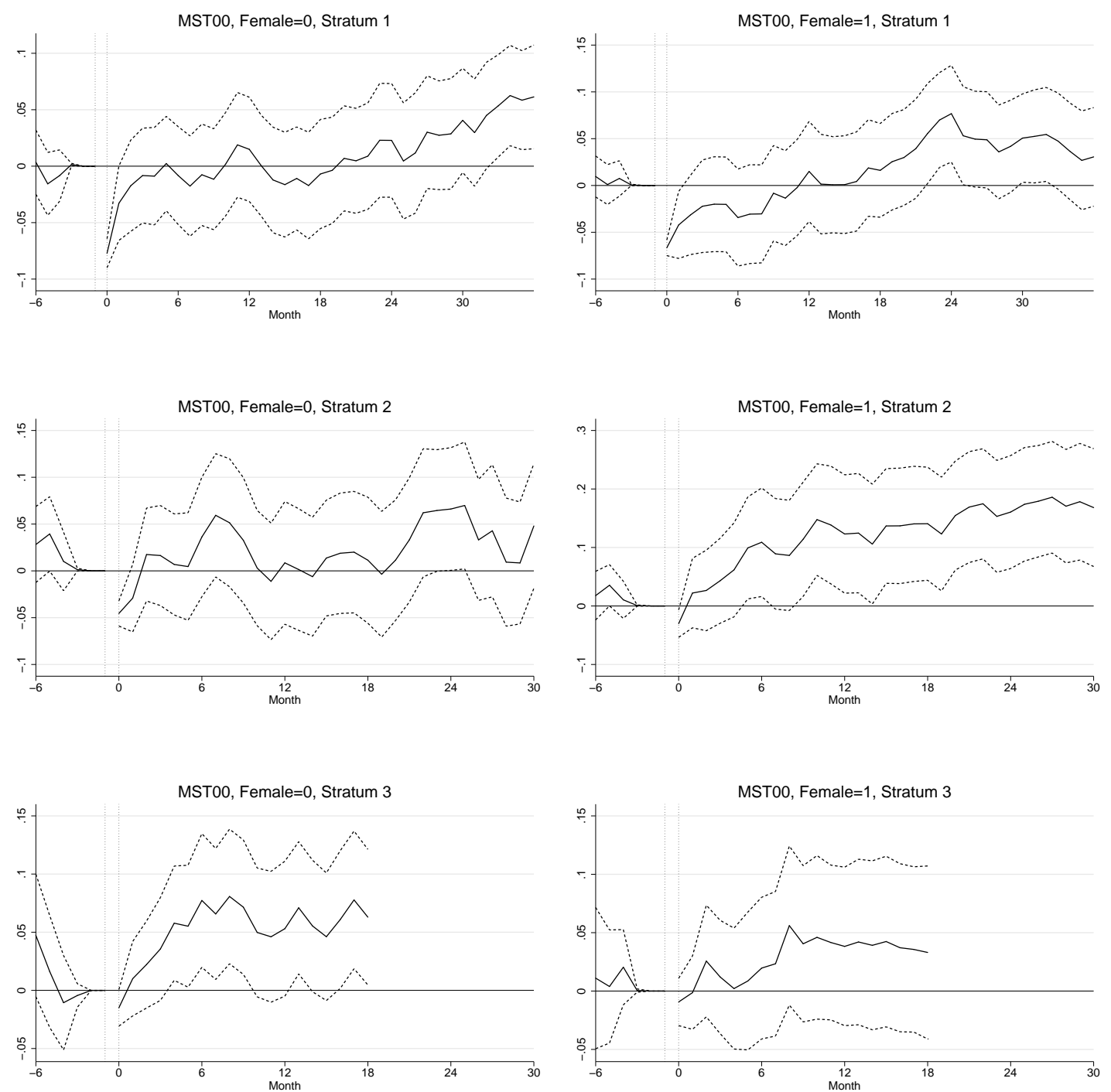

Difference in employment rates is measured on the ordinate, pre-unemployment $(<0)$ and posttreatment $(\geq 0)$ months on the abscissa. 
Figure 3: Average Treatment Effect on the Treated (ATT)
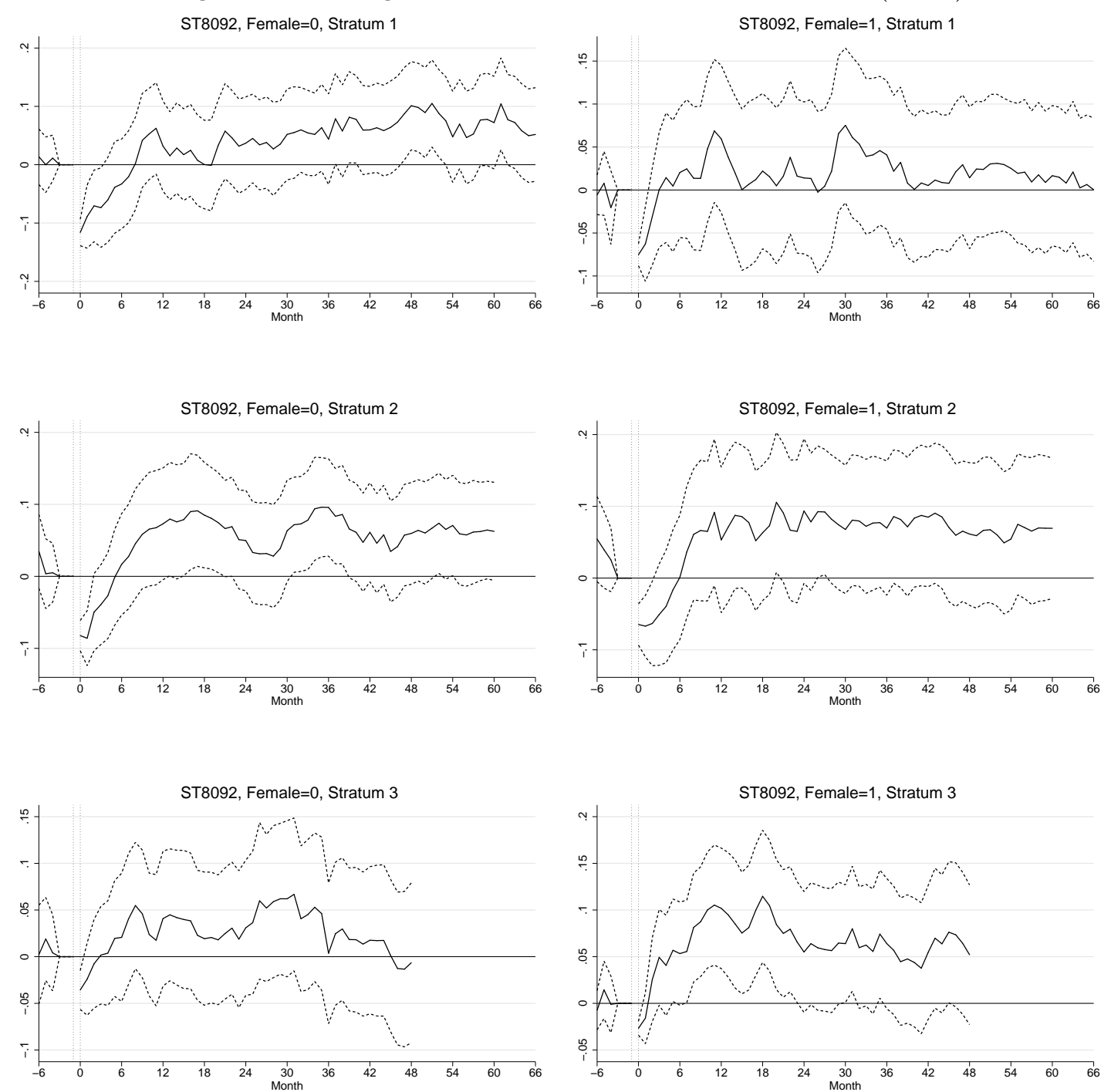

Difference in employment rates is measured on the ordinate, pre-unemployment $(<0)$ and posttreatment $(\geq 0)$ months on the abscissa. 


\section{Additional Appendix to: Déjà Vu? Short-Term Training in Germany 1982-1992 and 2000-2003}

Note: The following material is made available as additional information for the paper "Déjà Vu? Short-Term Training in Germany 1982-1992 and 2000-2003".

\section{Variable Definitions for the 2000-2003 Sample}

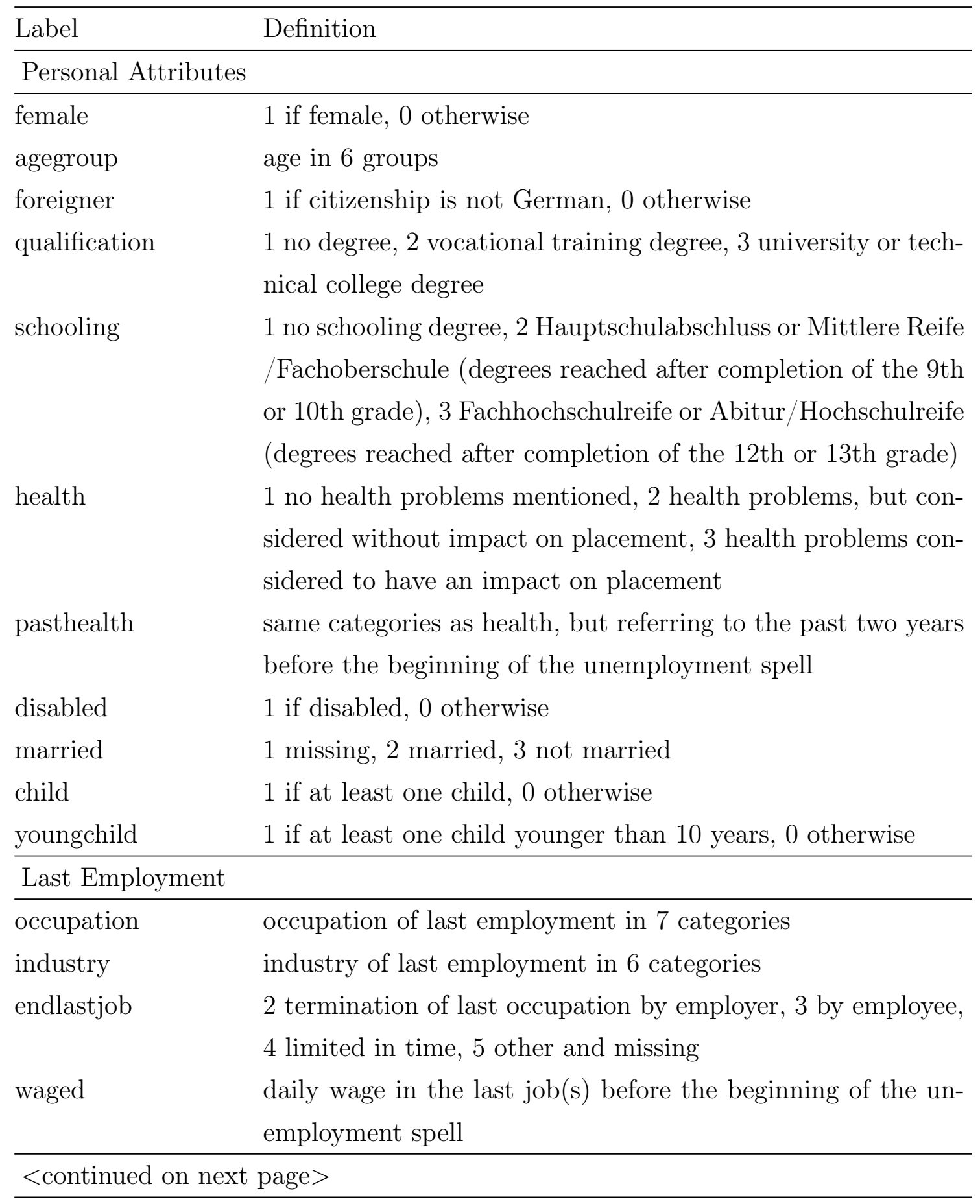




\begin{tabular}{|c|c|}
\hline Label & Definition \\
\hline ddssec & ddsec is 1 if earnings are within the social security thresholds \\
\hline lnwage & $\log$ (waged) interacted with ddssec \\
\hline \multicolumn{2}{|c|}{ Employment and Program History } \\
\hline problemgroup & $\begin{array}{l}1 \text { if participation in a program with a social work component } \\
\text { within the last three years, } 0 \text { otherwise }\end{array}$ \\
\hline pasttreatcancel & $\begin{array}{l}1 \text { if abandonment of a program in the past according to the } \\
\text { benefit data, } 0 \text { otherwise }\end{array}$ \\
\hline penalty & $\begin{array}{l}1 \text { if the unemployed had a period of disqualification from ben- } \\
\text { efits within the last three years, } 0 \text { otherwise }\end{array}$ \\
\hline motivationlack & $\begin{array}{l}1 \text { if within the last three years there is information, that the } \\
\text { person did not appear regularly at the labor office, on lack of } \\
\text { cooperation, availability or similar }\end{array}$ \\
\hline $\begin{array}{l}\text { countemp, coun- } \\
\text { tub, countua, } \\
\text { countsub, coun- } \\
\text { toos, countcon }\end{array}$ & $\begin{array}{l}\text { number of days within the last three years before the begin- } \\
\text { ning of unemployment spent in regular employment, receiv- } \\
\text { ing unemployment benefits, unemployment assistance, subsis- } \\
\text { tance payment, out of sample, in contact with the labor office, } \\
\text { respectively }\end{array}$ \\
\hline $\begin{array}{l}\text { dcount... } \\
\text { demp6, demp12, } \\
\text { demp24, } \\
\text { demp6_12, } \\
\text { demp12_24 }\end{array}$ & $\begin{array}{l}1 \text { if the respective count variable is larger than } 0,0 \text { otherwise } \\
1 \text { if in regular employment } 6,12,24,6 \text { and } 12 \text { and } 12 \text { and } 24 \\
\text { months, respectively, before the beginning of the unemploy- } \\
\text { ment spell }\end{array}$ \\
\hline claimg & remaining claim on unemployment benefit in four categories \\
\hline \multicolumn{2}{|l|}{ Regional Information } \\
\hline area & $\begin{array}{l}\text { German Bundesländer aggregated into } 6 \text { categories. } 1 \mathrm{SH}, \mathrm{NI} \text {, } \\
\mathrm{HB}, \mathrm{HH} ; 2 \mathrm{NW}, 3 \mathrm{HE}, \mathrm{RP}, \mathrm{SL} ; 4 \mathrm{BY}, \mathrm{BW} ; 5 \mathrm{MV}, \mathrm{BB}, \mathrm{BE} ; 6 \\
\mathrm{SN}, \mathrm{ST}, \mathrm{TH}\end{array}$ \\
\hline region & $\begin{array}{l}\text { classification of the districts of residence according to local } \\
\text { labor market conditions in } 5 \text { groups }\end{array}$ \\
\hline \multicolumn{2}{|c|}{ Calendar Time of Entry into Unemployment } \\
\hline quarter & quarter of the end of the last employment (from 1 to 6 ) \\
\hline
\end{tabular}

Note: If not mentioned otherwise, variables are defined relative to the beginning of the time window of elapsed unemployment duration. Variables in categories are used as dummies, i.e. agegroup1 is 1 if agegroup takes the value 1 and 0 otherwise. 


\section{Estimated Propensity Scores for the 2000-2003 Sample}

Participation Probit for QST00, Males

\begin{tabular}{|c|c|c|c|}
\hline \multicolumn{4}{|c|}{ Treatment QST00, Female $=0$} \\
\hline & Stratum 1 & Stratum 2 & Stratum 3 \\
\hline agegroup1 & & $-0.166(0.098)^{*}$ & $-0.160(0.120)$ \\
\hline agegroup12 & $0.001(0.041)$ & & \\
\hline agegroup2 & & $-0.123(0.088)$ & $-0.090(0.102)$ \\
\hline agegroup4 & & $-0.002(0.090)$ & $-0.082(0.107)$ \\
\hline agegroup5 & & $-0.080(0.105)$ & $0.214(0.102)^{* *}$ \\
\hline agegroup6 & & $0.140(0.106)$ & $0.145(0.113)$ \\
\hline area2 & & $-0.082(0.081)$ & $-0.151(0.085)^{*}$ \\
\hline area3 & & $-0.008(0.097)$ & $-0.125(0.113)$ \\
\hline area4 & & $-0.129(0.112)$ & $-0.319(0.130)^{* *}$ \\
\hline child & $0.116(0.048)^{* *}$ & $0.087(0.067)$ & $0.179(0.071)^{* *}$ \\
\hline claimg0 & & $-0.031(0.105)$ & $0.043(0.095)$ \\
\hline claimg1 & $0.130(0.103)$ & & \\
\hline claimg2 & $0.116(0.088)$ & $-0.124(0.085)$ & $-0.072(0.101)$ \\
\hline claimg3 & $0.096(0.098)$ & & \\
\hline claimg34 & & $-0.383(0.116)^{* * *}$ & $-0.210(0.119)^{*}$ \\
\hline claimg4 & $0.169(0.108)$ & & \\
\hline countcon & $0(0.000)$ & $0(0.000)$ & $0(0.000)^{*}$ \\
\hline countemp & $0(0.000)^{* *}$ & $0.001(0.000)^{* * *}$ & $0(0.000)$ \\
\hline dcountcon & $0.068(0.053)$ & $0.021(0.079)$ & $0.029(0.086)$ \\
\hline dcountoos & & $0.011(0.078)$ & $-0.148(0.086)^{*}$ \\
\hline dcountsub & $0.214(0.071)^{* * *}$ & & \\
\hline ddssec & $0.607(0.242)^{* *}$ & & \\
\hline demp12_24 & $0.195(0.074)^{* * *}$ & $-0.045(0.115)$ & $0.055(0.144)$ \\
\hline demp24 & $-0.150(0.076)^{* *}$ & $0.010(0.121)$ & $0.009(0.144)$ \\
\hline demp6 & $0.026(0.063)$ & $-0.033(0.097)$ & $0.292(0.114)^{* *}$ \\
\hline endlastjob2 & $0.045(0.046)$ & & \\
\hline endlastjob4 & $0.236(0.064)^{* * *}$ & & \\
\hline industry3 & & $-0.162(0.086)^{*}$ & $-0.267(0.095)^{* * *}$ \\
\hline industry5 & & $0.095(0.078)$ & $-0.192(0.099)^{*}$ \\
\hline industry6 & & $-0.027(0.097)$ & $-0.151(0.104)$ \\
\hline lnwaged & $-0.135(0.053)^{* *}$ & & \\
\hline married2 & $0.165(0.044)^{* * *}$ & $0.167(0.065)^{* *}$ & $0.281(0.071)^{* * *}$ \\
\hline motivationlack & $0.105(0.055)^{*}$ & & \\
\hline occupation1 & $0.102(0.073)$ & & \\
\hline occupation3 & $-0.013(0.065)$ & & \\
\hline occupation5 & $0.243(0.080)^{* * *}$ & & \\
\hline occupation6 & $0.139(0.086)$ & & \\
\hline occupation7 & $-0.002(0.105)$ & & \\
\hline problemgroup & $0.224(0.092)^{* *}$ & & \\
\hline quarter1 & $-0.199(0.054)^{* * *}$ & $-0.196(0.105)^{*}$ & $-0.154(0.104)$ \\
\hline quarter2 & & $0.029(0.104)$ & $-0.211(0.117)^{*}$ \\
\hline quarter3 & & $0.091(0.095)$ & $-0.182(0.110)^{*}$ \\
\hline quarter4 & $-0.120(0.051)^{* *}$ & $-0.062(0.094)$ & $-0.122(0.100)$ \\
\hline quarter5 & $-0.086(0.049)^{*}$ & & \\
\hline quarter6 & & $0.121(0.093)$ & $-0.115(0.101)$ \\
\hline region2 & & $-0.237(0.097)^{* *}$ & $-0.092(0.096)$ \\
\hline region4 & & $0.090(0.104)$ & $0.157(0.115)$ \\
\hline region5 & & $0.038(0.095)$ & $0.225(0.115)^{*}$ \\
\hline schooling3 & $0.143(0.060)^{* *}$ & & \\
\hline youngchild & $-0.048(0.062)$ & & \\
\hline _cons & $-2.633(0.169)^{* * *}$ & $-2.354(0.231)^{* * *}$ & $-1.961(0.265)^{* * *}$ \\
\hline$\overline{\mathrm{N}}$ & 21538 & 8558 & 5333 \\
\hline
\end{tabular}


Results for Smith and Todd (2005) Balancing Test, QST00 Males

\begin{tabular}{l|llll}
\hline \multicolumn{5}{c}{ Treatment QST00, Female=0, Cubic of Pscore } \\
\hline & P-values $>.1$ & P-values $>.05$ & P-values $>.01$ & Regressors \\
\hline Stratum 1 & 28 & 29 & 30 & 30 \\
Stratum 2 & 27 & 30 & 31 & 31 \\
Stratum 3 & 28 & 30 & 31 & 31 \\
\hline \multicolumn{5}{r}{} \\
\hline \multicolumn{5}{r}{ Treatment QST00, Female=0, Quartic of Pscore } \\
\hline Stratum 1 & P-values $>.1$ & P-values $>.05$ & P-values $>.01$ & Regressors \\
Stratum 2 & 28 & 28 & 30 & 30 \\
Stratum 3 & 26 & 27 & 31 & 31 \\
\hline
\end{tabular}


Participation Probit for MST00, Males

\begin{tabular}{|c|c|c|c|}
\hline \multicolumn{4}{|c|}{ Treatment MST00, Female $=0$} \\
\hline & Stratum 1 & Stratum 2 & Stratum 3 \\
\hline agegroup1 & & $0.063(0.095)$ & \\
\hline agegroup2 & & $0.231(0.080)^{* * *}$ & \\
\hline agegroup 56 & $-0.033(0.050)$ & $0.006(0.098)$ & \\
\hline child & & $0.189(0.072)^{* * *}$ & $0.115(0.068)^{*}$ \\
\hline claimg0 & $-0.027(0.079)$ & $-0.059(0.215)$ & $0.142(0.097)$ \\
\hline claimg0_dcountoos & & $0.370(0.206)^{*}$ & \\
\hline claimg1- & $0.053(0.084)$ & $-0.040(0.195)$ & $-0.085(0.108)$ \\
\hline claimg1_dcountoos & & $0.286(0.204)$ & \\
\hline claimg2 & & $0.221(0.107)^{* *}$ & \\
\hline claimg34 & $0.008(0.047)$ & & $-0.124(0.117)$ \\
\hline countub & & & $-0(0.000)$ \\
\hline dcountcon & $0.091(0.054)^{*}$ & & $0.129(0.084)$ \\
\hline dcountoos & $0.064(0.042)$ & $-0.169(0.091)^{*}$ & \\
\hline dcountsub & & & $0.237(0.112)^{* *}$ \\
\hline dcountub & $-0.135(0.046)^{* * *}$ & & \\
\hline demp12 & & $0.005(0.151)$ & $0.029(0.138)$ \\
\hline demp24 & & $-0.029(0.080)$ & $0.054(0.073)$ \\
\hline demp6_12 & $0.124(0.050)^{* *}$ & $0.106(0.153)$ & $-0.127(0.133)$ \\
\hline endlastjob2 & $0.102(0.046)^{* *}$ & & \\
\hline endlastjob3 & $-0.172(0.117)$ & & \\
\hline endlastjob4 & $0.135(0.071)^{*}$ & & \\
\hline foreigner & & $-0.291(0.096)^{* * *}$ & \\
\hline health2 & & $0.284(0.127)^{* *}$ & \\
\hline health3 & & $-0.110(0.135)$ & \\
\hline industry2 & $0.520(0.171)^{* * *}$ & & \\
\hline industry3 & $0.314(0.171)^{*}$ & & $-0.093(0.099)$ \\
\hline industry 4 & $0.432(0.170)^{* *}$ & & $-0.067(0.085)$ \\
\hline industry 5 & $0.500(0.173)^{* * *}$ & & $-0.150(0.103)$ \\
\hline industry 6 & $0.350(0.180)^{*}$ & & $-0.321(0.121)^{* * *}$ \\
\hline married2 & $0.129(0.042)^{* * *}$ & $0.220(0.069)^{* * *}$ & $0.234(0.071)^{* * *}$ \\
\hline motivationlack & $0.109(0.055)^{* *}$ & & $-0.027(0.078)$ \\
\hline pasthealth1 & & & $0.346(0.123)^{* * *}$ \\
\hline pasthealth2 & & $-0.063(0.172)$ & \\
\hline pasthealth3 & & $0.312(0.149)^{* *}$ & \\
\hline penalty & & & $0.219(0.126)^{*}$ \\
\hline qualification1 & $0.107(0.041)^{* * *}$ & $0.182(0.068)^{* * *}$ & $0.041(0.066)$ \\
\hline quarter1 & $0(0.070)$ & & \\
\hline quarter3 & $0.008(0.075)$ & & \\
\hline quarter4 & $-0.056(0.071)$ & & $0.098(0.088)$ \\
\hline quarter5 & $-0.034(0.070)$ & & $0.186(0.084)^{* *}$ \\
\hline quarter6 & $0.161(0.071)^{* *}$ & & $0.141(0.092)$ \\
\hline region2 & $0.536(0.079)^{* * *}$ & & \\
\hline region3 & $0.278(0.074)^{* * *}$ & $-0.037(0.086)$ & $-0.140(0.082)^{*}$ \\
\hline region4 & & $-0.194(0.126)$ & $-0.258(0.121)^{* *}$ \\
\hline region5 & $0.122(0.080)$ & $-0.169(0.102)^{*}$ & $-0.283(0.101)^{* * *}$ \\
\hline schooling3 & $0.090(0.057)$ & & \\
\hline cons & $-2.961(0.207)^{* * *}$ & $-2.406(0.170)^{* * *}$ & $-2.176(0.206)^{* * *}$ \\
\hline$\overline{\mathrm{N}}$ & 21510 & 8514 & 5336 \\
\hline
\end{tabular}


Results for Smith and Todd (2005) Balancing Test, MST00 Males

\begin{tabular}{l|llll}
\hline \multicolumn{5}{c}{ Treatment } \\
\hline & PST00, Female=0, Cubic of Pscore & Regressors \\
\hline Stratum 1 & 26 & P-values $>.05$ & P-values $>.01$ & 28 \\
Stratum 2 & 23 & 28 & 28 & 23 \\
Stratum 3 & 23 & 23 & 23 & 25 \\
\hline
\end{tabular}

Treatment MST00, Female $=0$, Quartic of Pscore

\begin{tabular}{l|llll}
\hline & P-values $>.1$ & P-values $>.05$ & P-values $>.01$ & Regressors \\
\hline Stratum 1 & 26 & 27 & 28 & 28 \\
Stratum 2 & 20 & 23 & 23 & 23 \\
Stratum 3 & 22 & 23 & 25 & 25 \\
\hline
\end{tabular}


Participation Probit for QST00, Females

\begin{tabular}{|c|c|c|c|}
\hline \multicolumn{4}{|c|}{ Treatment QST00, Female $=1$} \\
\hline & Stratum 1 & Stratum 2 & Stratum 3 \\
\hline agegroup12 & $-0.113(0.048)^{* *}$ & & $-0.228(0.099)^{* *}$ \\
\hline agegroup 4 & & $0.193(0.080)^{* *}$ & \\
\hline agegroup 56 & $-0.021(0.053)$ & $0.155(0.081)^{*}$ & $0.158(0.094)^{*}$ \\
\hline child & $0.116(0.045)^{* *}$ & $0.223(0.068)^{* * *}$ & $0.197(0.088)^{* *}$ \\
\hline claimg0 & $-0.042(0.127)$ & $0.187(0.122)$ & $0.242(0.118)^{* *}$ \\
\hline claimg2 & $0.166(0.095)^{*}$ & $0.254(0.109)^{* *}$ & $0.143(0.126)$ \\
\hline claimg34 & $0.173(0.100)^{*}$ & $0.126(0.149)$ & $0.153(0.141)$ \\
\hline claimg34_married2 & & $0.242(0.170)$ & \\
\hline countcon- & $0(0.000)$ & $0.001(0.000)^{*}$ & $0(0.000)$ \\
\hline countemp & $0(0.000)$ & $0(0.000)$ & $-0(0.001)$ \\
\hline countoos & & $0.001(0.000)$ & $0(0.000)$ \\
\hline dcountcon & $0.135(0.057)^{* *}$ & & \\
\hline dcountoos & $-0.084(0.054)$ & & \\
\hline dcountua & & $0.170(0.108)$ & \\
\hline dcountub & & $0.087(0.088)$ & \\
\hline ddssec & $-4.380(1.263)^{* * *}$ & & \\
\hline demp12 & $0.049(0.133)$ & $0.075(0.188)$ & $-0.178(0.277)$ \\
\hline demp12_24 & $-0.037(0.076)$ & $0.072(0.120)$ & $0.239(0.159)$ \\
\hline demp6 & $0.027(0.092)$ & $0.027(0.126)$ & $0.235(0.159)$ \\
\hline demp6_12 & $-0.015(0.136)$ & $0.034(0.198)$ & $0.145(0.275)$ \\
\hline endlastjob2 & $0.227(0.056)^{* * *}$ & $0.375(0.084)^{* * *}$ & \\
\hline endlastjob3 & $0.291(0.075)^{* * *}$ & $0.139(0.123)$ & \\
\hline endlastjob4 & $0.081(0.072)$ & $0.122(0.113)$ & \\
\hline foreigner & & $-0.301(0.115)^{* * *}$ & \\
\hline health2 & $-0.271(0.143)^{*}$ & & \\
\hline health3 & $0.079(0.139)$ & & $0.234(0.117)^{* *}$ \\
\hline industry3 & $0.282(0.118)^{* *}$ & & \\
\hline industry4 & $0.062(0.058)$ & $0.172(0.085)^{* *}$ & \\
\hline industry 5 & $0.068(0.067)$ & $0.044(0.102)$ & \\
\hline industry 6 & $0.015(0.061)$ & $0.030(0.090)$ & \\
\hline lnwaged & $2.241(0.660)^{* * *}$ & & \\
\hline lnwagedsq & $-0.281(0.086)^{* * *}$ & & \\
\hline married2 & $0.222(0.044)^{* * *}$ & $0.200(0.074)^{* * *}$ & $0.455(0.083)^{* * *}$ \\
\hline motivationlack & & $-0.082(0.085)$ & \\
\hline pasthealth2 & $0.326(0.138)^{* *}$ & & \\
\hline pasthealth3 & $-0.041(0.147)$ & & \\
\hline pasttreatcancel & & $0.155(0.339)$ & \\
\hline penalty & & $0.332(0.159)^{* *}$ & \\
\hline problemgroup & $0.240(0.117)^{* *}$ & & \\
\hline region2 & $0.075(0.058)$ & & \\
\hline region3 & & $0.026(0.096)$ & \\
\hline region4 & & $0.086(0.123)$ & \\
\hline region5 & & $0.114(0.100)$ & \\
\hline _cons & $-2.408(0.224)^{* * *}$ & $-3.386(0.470)^{* * *}$ & $-2.733(0.521)^{* * *}$ \\
\hline $\bar{N}$ & 14385 & 7284 & 5105 \\
\hline
\end{tabular}


Results for Smith and Todd (2005) Balancing Test, QST00 Females

\begin{tabular}{l|llll}
\hline \multicolumn{5}{c}{ Treatment QST00, Female=1, Cubic of Pscore } \\
\hline & P-values $>.1$ & P-values $>.05$ & P-values $>.01$ & Regressors \\
\hline Stratum 1 & 30 & 31 & 31 & 31 \\
Stratum 2 & 28 & 29 & 30 & 30 \\
Stratum 3 & 15 & 15 & 15 & 15
\end{tabular}

Treatment QST00, Female=1, Quartic of Pscore

\begin{tabular}{l|llll}
\hline & P-values $>.1$ & P-values $>.05$ & P-values $>.01$ & Regressors \\
\hline Stratum 1 & 30 & 31 & 31 & 31 \\
Stratum 2 & 24 & 29 & 30 & 30 \\
Stratum 3 & 14 & 14 & 15 & 15 \\
\hline
\end{tabular}


Participation Probit for MST00, Females

\begin{tabular}{|c|c|c|c|}
\hline \multicolumn{4}{|c|}{ Treatment MST00, Female $=1$} \\
\hline & Stratum 1 & Stratum 2 & Stratum 3 \\
\hline agegroup1 & & $-0.175(0.117)$ & \\
\hline agegroup2 & & $-0.207(0.106)^{*}$ & \\
\hline agegroup4 & & & $0.261(0.115)^{* *}$ \\
\hline agegroup5 & & & $0.280(0.116)^{* *}$ \\
\hline agegroup56 & $-0.262(0.098)^{* * *}$ & $-0.169(0.123)$ & \\
\hline agegroup6 & & & $0.372(0.117)^{* * *}$ \\
\hline area3 & & $-0.214(0.111)^{*}$ & \\
\hline child & $0.213(0.055)^{* * *}$ & $0.104(0.089)$ & \\
\hline claimg0 & $-0.045(0.117)$ & $0.324(0.147)^{* *}$ & $0.178(0.117)$ \\
\hline claimg1 & $-0.070(0.109)$ & $0.105(0.126)$ & $-0.053(0.132)$ \\
\hline claimg3 & $0.098(0.101)$ & $-0.143(0.133)$ & \\
\hline claimg34 & & & $-0.066(0.129)$ \\
\hline claimg3_dcountoos & $-0.114(0.116)$ & & \\
\hline claimg4 & $0.506(0.140)^{* * *}$ & $0.023(0.164)$ & \\
\hline claimg4_dcountoos & $-0.380(0.182)^{* *}$ & & \\
\hline countoos & & $0(0.000)$ & $-0(0.000)$ \\
\hline countub & & $-0.001(0.001)$ & $-0.001(0.000)$ \\
\hline dcountcon & $0.066(0.062)$ & $0.073(0.094)$ & \\
\hline dcountoos & $0.154(0.092)^{*}$ & & \\
\hline dcountsub & & & $0.264(0.163)$ \\
\hline demp12 & $0.059(0.090)$ & $-0.174(0.242)$ & $-0.288(0.127)^{* *}$ \\
\hline demp12_24 & $0.045(0.131)$ & & \\
\hline demp24 & $0.037(0.130)$ & $0.021(0.156)$ & $-0.120(0.141)$ \\
\hline demp6 & $0.095(0.087)$ & & \\
\hline demp6_12 & & $0.295(0.245)$ & \\
\hline endlastjob2 & $0.147(0.065)^{* *}$ & $0.161(0.089)^{*}$ & \\
\hline endlastjob3 & $0.229(0.089)^{* *}$ & & \\
\hline endlastjob4 & $0.138(0.080)^{*}$ & $0.189(0.116)$ & \\
\hline lncountemp & $-0.087(0.092)$ & $-1.548(1.464)$ & $-0.626(1.361)$ \\
\hline lncountempsq & & $0.135(0.131)$ & $0.062(0.119)$ \\
\hline married2 & $0.201(0.054)^{* * *}$ & $0.271(0.080)^{* * *}$ & $0.193(0.087)^{* *}$ \\
\hline onlyparttime & $-0.120(0.066)^{*}$ & & \\
\hline parttime & & $-0.005(0.079)$ & $-0.073(0.084)$ \\
\hline qualification1 & $0.148(0.053)^{* * *}$ & & $0.173(0.083)^{* *}$ \\
\hline quarter1 & $0.295(0.087)^{* * *}$ & $0.282(0.140)^{* *}$ & \\
\hline quarter2 & $0.235(0.092)^{* *}$ & $0.263(0.149)^{*}$ & $0.141(0.167)$ \\
\hline quarter3 & $0.275(0.088)^{* * *}$ & $0.375(0.136)^{* * *}$ & $0.169(0.162)$ \\
\hline quarter4 & & & $0.317(0.151)^{* *}$ \\
\hline quarter5 & $0.350(0.083)^{* * *}$ & $0.225(0.137)^{*}$ & $0.232(0.151)$ \\
\hline quarter6 & $0.231(0.091)^{* *}$ & $0.413(0.136)^{* * *}$ & $0.337(0.153)^{* *}$ \\
\hline region2 & $0.457(0.100)^{* * *}$ & $0.312(0.132)^{* *}$ & $0.460(0.169)^{* * *}$ \\
\hline region3 & $0.309(0.091)^{* * *}$ & $0.426(0.103)^{* * *}$ & $0.355(0.156)^{* *}$ \\
\hline region4 & & $0.129(0.154)$ & \\
\hline region5 & $0.150(0.097)$ & & $0.099(0.172)$ \\
\hline schooling3 & $0.084(0.064)$ & & \\
\hline youngchild & & $-0.232(0.121)^{*}$ & $0.353(0.105)^{* * *}$ \\
\hline _cons & $-2.563(0.540)^{* * *}$ & $1.394(4.026)$ & $-1.093(3.846)$ \\
\hline $\mathrm{N}$ & 14173 & 7196 & 5090 \\
\hline
\end{tabular}


Results for Smith and Todd (2005) Balancing Test, MST00 Females

\begin{tabular}{l|llll}
\hline \multicolumn{5}{c}{ Treatment } \\
\hline & PST00, Female=1, Cubic of Pscore & Regressors \\
\hline Stratum 1 & 25 & P-values $>.05$ & P-values $>.01$ & 30 \\
Stratum 2 & 29 & 28 & 30 & 30 \\
Stratum 3 & 22 & 29 & 30 & 25 \\
\hline
\end{tabular}

Treatment MST00, Female=1, Quartic of Pscore

\begin{tabular}{l|llll}
\hline & P-values $>.1$ & P-values $>.05$ & P-values $>.01$ & Regressors \\
\hline Stratum 1 & 27 & 29 & 30 & 30 \\
Stratum 2 & 28 & 30 & 30 & 30 \\
Stratum 3 & 20 & 23 & 25 & 25 \\
\hline
\end{tabular}

Figure 4: Graphical Check of Common Support for QST00
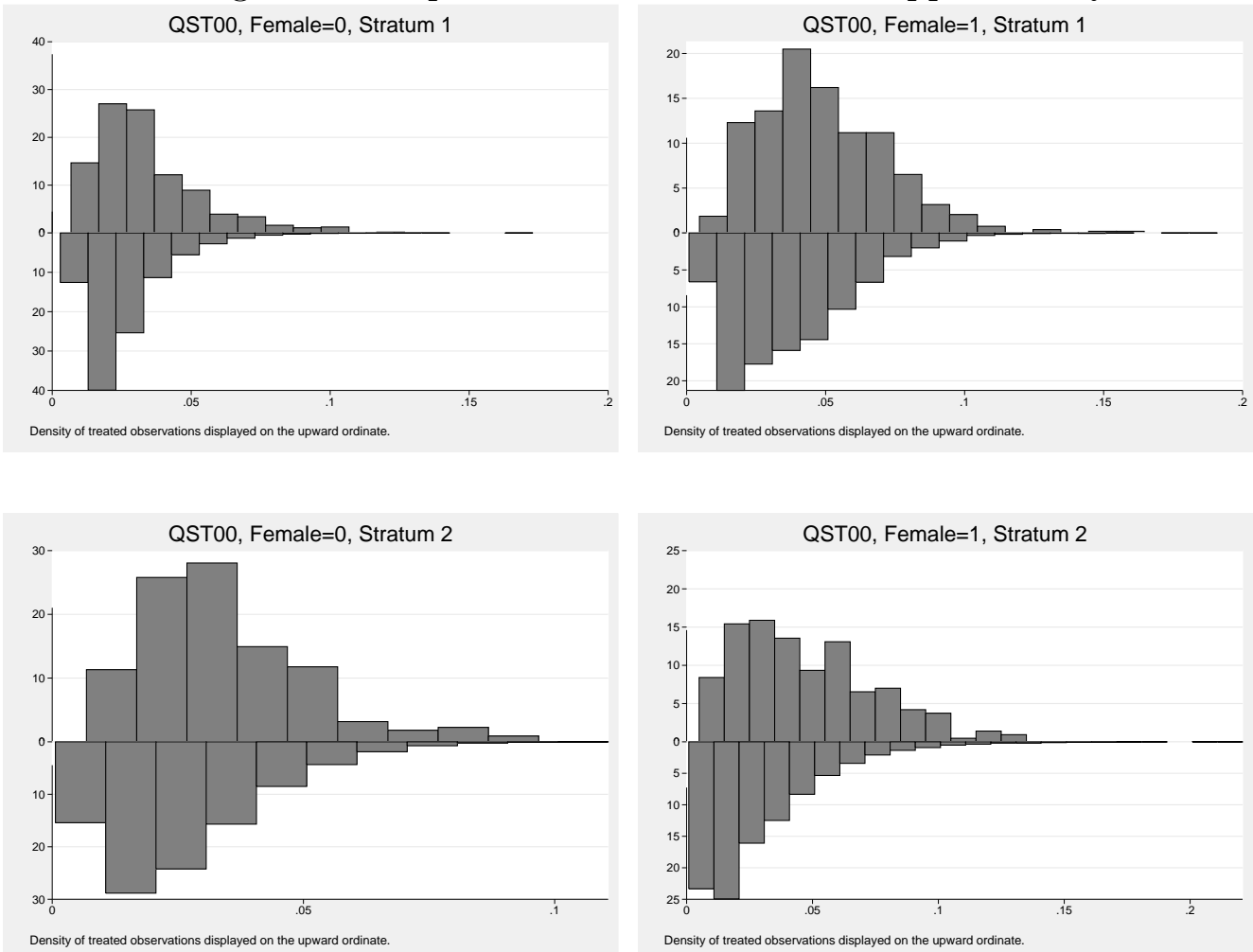

Density of treated observations displayed on the upward ordinate.

Density of treated observations displayed on the upward ordinate
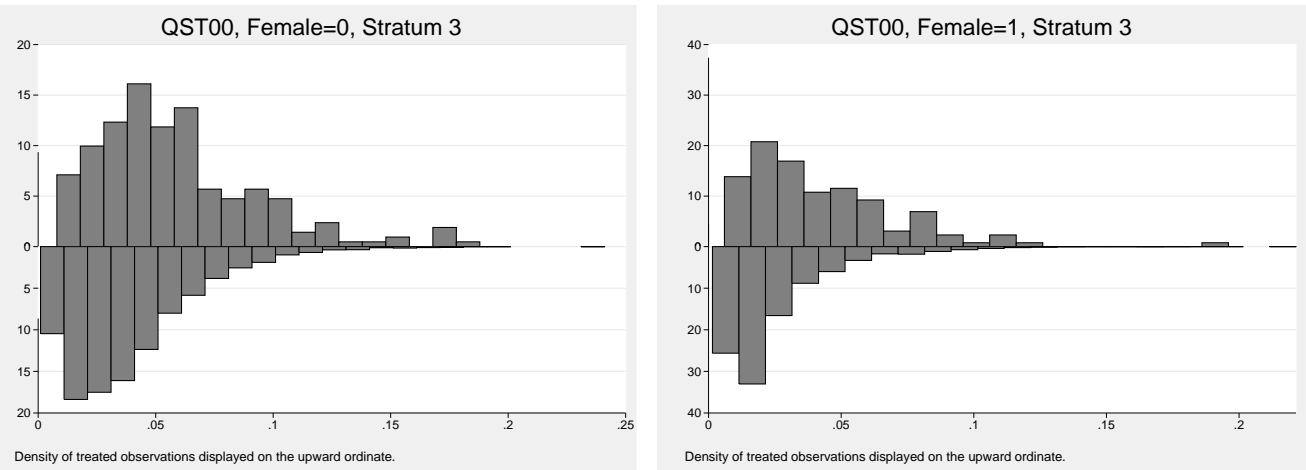
Figure 5: Graphical Check of Common Support for MST00 MST00, Female=0, Stratum 1

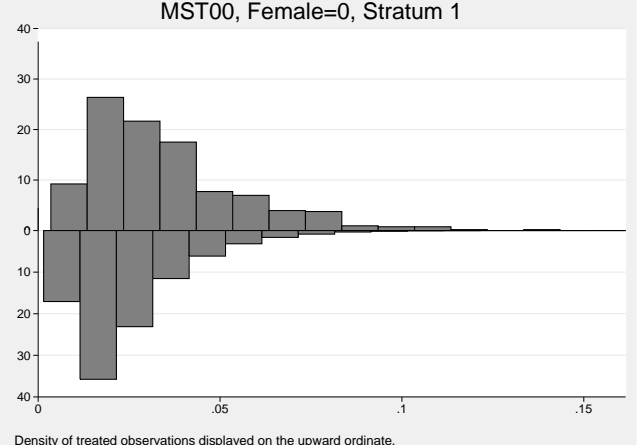

MST00, Female $=1$, Stratum 1
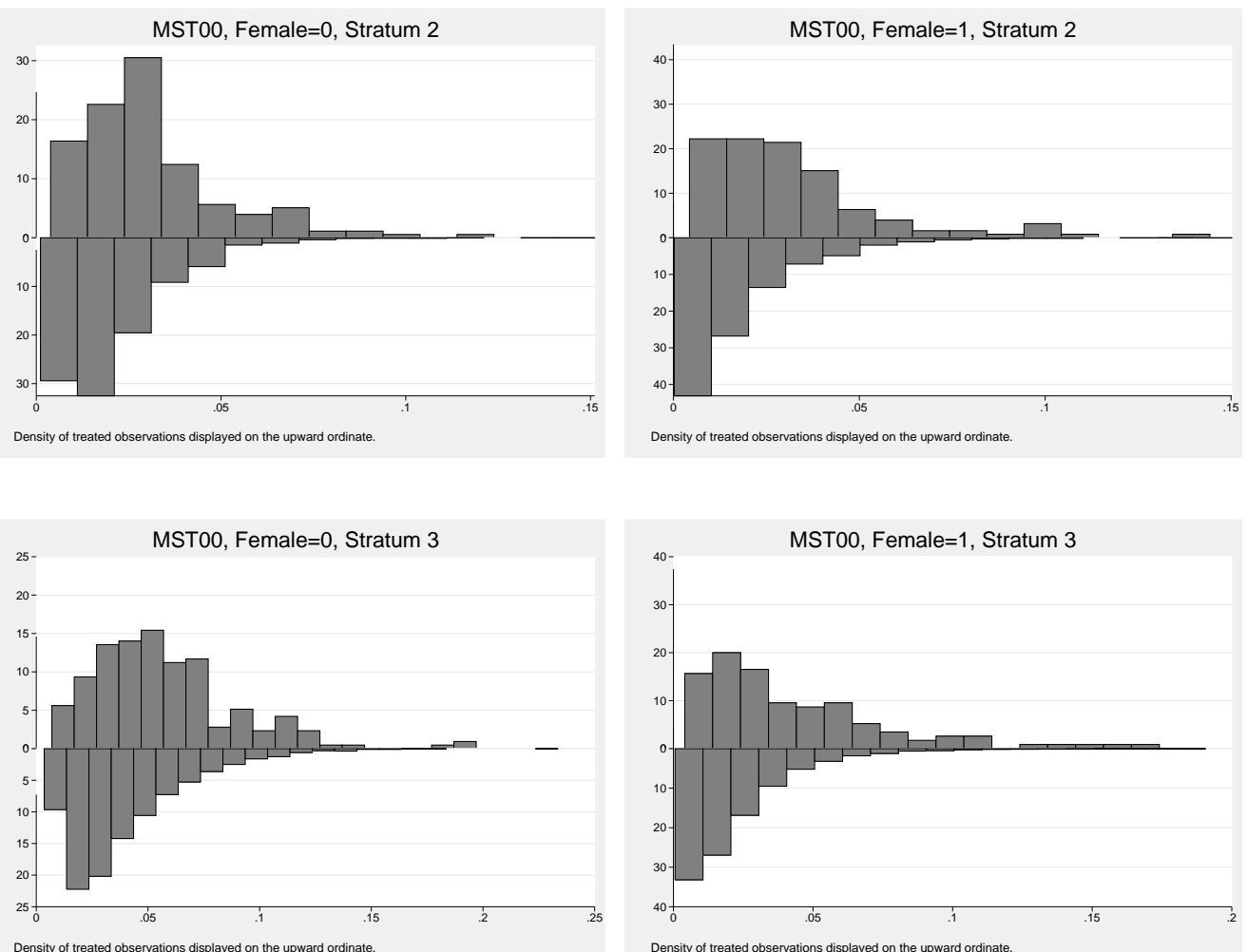


\section{Variable Definitions for the 1980-1992 Sample}

\begin{tabular}{|c|c|}
\hline Label & Definition \\
\hline \multicolumn{2}{|c|}{ Personal Attributes } \\
\hline aXXYY & Age at start of unemployment $\geq \mathrm{XX}$ and $\leq \mathrm{YY}$ \\
\hline age & Age at start of unemployment \\
\hline lnage & $\ln ($ age $)$ at start of unemployment \\
\hline female & Female \\
\hline foreign & No German citizenship \\
\hline kids & Has dependent children \\
\hline married & Married \\
\hline BIL1 & No vocational training degree \\
\hline BIL2 & Vocational training degree \\
\hline BIL3 & Abitur/No vocational training degree \\
\hline BIL4 & University/College degree \\
\hline \multicolumn{2}{|c|}{ Last Employment } \\
\hline$\overline{\text { BER1 }}$ & Apprentice \\
\hline BER2 & Blue Collar Worker \\
\hline BER3 & White Collar Worker \\
\hline BER4 & Worker at home with low hours or BER missing \\
\hline BER5 & Part-time working \\
\hline pentg & Daily earnings $\geq 15$ Euro per day in 1995 Euro \\
\hline entgcens & Earnings censored at social security taxation threshold \\
\hline entg & Daily earnings if pentg $=1$ and entgcens $=0$, otherwise zero \\
\hline logentg & $\log$ of entg if pentg $=1$ and entgcens $=0$, otherwise zero \\
\hline claim0 & $\begin{array}{l}\text { Remaining claim on unemployment benefit at beginning of } \\
\text { Stratum } 1\end{array}$ \\
\hline claim181 & $\begin{array}{l}\text { Remaining claim on unemployment benefit at beginning of } \\
\text { Stratum } 2\end{array}$ \\
\hline claim361 & $\begin{array}{l}\text { Remaining claim on unemployment benefit at beginning of } \\
\text { Stratum } 3\end{array}$ \\
\hline \multicolumn{2}{|c|}{$\operatorname{lnclaimX}(\mathrm{X}=0, \ln ($ claim $\mathrm{X})$} \\
\hline 181,361$)$ & \\
\hline claimXg0 & $\operatorname{claim} X=0$ \\
\hline claimXg1 & claim $X>0$ and claim $0 \leq 170$ \\
\hline claimXg2 & claimX $>170$ and claim0 $\leq 350$ \\
\hline claimXg3 & claimX $>350$ \\
\hline \multicolumn{2}{|c|}{ Last Employer } \\
\hline WZW1 & Agriculture \\
\hline WZW2 & Basic materials \\
\hline WZW3 & Metal, vehicles, electronics \\
\hline WZW4 & Light industry \\
\hline WZW5 & Construction \\
\hline WZW6 & Production oriented services, trade, banking \\
\hline WZW7 & Consumer oriented services, organization and social services \\
\hline frmsize1 & Firm Size (employment) missing or $\leq 10$ \\
\hline frmsize2 & Firm Size (employment) $>10$ and $\leq 200$ \\
\hline
\end{tabular}




\begin{tabular}{|c|c|}
\hline Label & Definition \\
\hline frmsize3 & Firm Size (employment) $>200$ and $\leq 500$ \\
\hline frmsize4 & Firm Size (employment) $>500$ \\
\hline \multicolumn{2}{|c|}{ Employment and Program History } \\
\hline preexM & $\begin{array}{l}\text { Employed M }(\mathrm{M}=6,12,24) \text { month before unemployment } \\
\text { starts }\end{array}$ \\
\hline preex6cum & $\begin{array}{l}\text { Number of months employed in the last } 6 \text { months before un- } \\
\text { employment starts }\end{array}$ \\
\hline preex12cum & $\begin{array}{l}\text { Number of months employed in the last } 12 \text { months before } \\
\text { unemployment starts }\end{array}$ \\
\hline preex 24 cum & $\begin{array}{l}\text { Number of months employed in the last } 24 \text { months before } \\
\text { unemployment starts }\end{array}$ \\
\hline preex60cum & $\begin{array}{l}\text { Number of months employed in the last } 60 \text { months before } \\
\text { unemployment starts }\end{array}$ \\
\hline $\operatorname{pretx} Y$ & $\begin{array}{l}\text { Participation in any ALMP program reported in our data in } \\
\text { year(s) } Y(Y=1,2) \text { before unemployment starts }\end{array}$ \\
\hline \multicolumn{2}{|c|}{ Regional Information } \\
\hline$\overline{\mathrm{LAND} 6}$ & Schleswig-Holstein/Hamburg \\
\hline LAND7 & Niedersachsen/Bremen \\
\hline LAND8 & Nordrhein-Westfalen \\
\hline LAND9 & Hessen \\
\hline LAND10 & Rheinland-Pfalz/Saarland \\
\hline LAND11 & Baden-Württemberg \\
\hline LAND12 & Bayern \\
\hline \multicolumn{2}{|c|}{ Calendar Time of Entry into Unemployment } \\
\hline tnull & First unemployment month (January $1960=0$ ) \\
\hline y19YY & Unemployment begins in year $19 \mathrm{YY}$ \\
\hline \multicolumn{2}{|c|}{ Interaction of Variables } \\
\hline south & Baden-Württemberg/Bayern \\
\hline middle & Hessen/Rheinland-Pfalz/Saarland \\
\hline north & Schleswig-Holstein/Hamburg/Niedersachsen/Bremen \\
\hline BILXBERY & Combination of education- and job-status-variables \\
\hline yXXYY & Unemployment begins between year 19XX and 19YY \\
\hline
\end{tabular}

All variables except those referring to benefit claims are defined at the time of entry into unemployment and constant during the unemployment spell. 


\section{Estimated Propensity Scores for the 1980-1992 Sample}

Participation Probit for ST8092, Males

\begin{tabular}{|c|c|c|c|}
\hline \multicolumn{4}{|c|}{ Treatment ST8092, Female $=0$} \\
\hline & Stratum 1 & Stratum 2 & Stratum 3 \\
\hline$\overline{\text { BER2 }}$ & & $-0.201(0.186)$ & $0.123(0.072)^{*}$ \\
\hline BER3 & $0.229(0.072)^{* * *}$ & & \\
\hline BIL1BER2 & $0.114(0.072)$ & $0.365(0.242)$ & \\
\hline BIL1BER3 & & $0.636(0.288)^{* *}$ & \\
\hline BIL1a3034 & & $0.341(0.144)^{* *}$ & \\
\hline BIL1a3544 & & $-0.511(0.252)^{* *}$ & \\
\hline BIL2 & & $0.429(0.222)^{*}$ & \\
\hline BIL2BER3 & & $-0.068(0.192)$ & \\
\hline BIL2a3544 & & $-0.416(0.223)^{*}$ & \\
\hline BIL4 & $-0.188(0.123)$ & & \\
\hline LAND10 & $0.286(0.086)^{* * *}$ & & \\
\hline LAND8 & $0.169(0.061)^{* * *}$ & & \\
\hline LAND9 & $0.262(0.084)^{* * *}$ & & \\
\hline WZW1 & $0.235(0.146)$ & & \\
\hline WZW2 & $0.231(0.098)^{* *}$ & & \\
\hline WZW3 & $0.301(0.086)^{* * *}$ & $0.177(0.073)^{* *}$ & \\
\hline WZW6 & $0.184(0.080)^{* *}$ & $0.125(0.060)^{* *}$ & \\
\hline WZW7 & $0.121(0.095)$ & & \\
\hline a3044 & & & $0.161(0.058)^{* * *}$ \\
\hline a3544 & & $0.520(0.217)^{* *}$ & \\
\hline a4553 & $-0.183(0.076)^{* *}$ & & \\
\hline claim0 & $-0.002(0.001)^{*}$ & & \\
\hline claim0g0 & $-0.466(0.353)$ & & \\
\hline claim0g1 & $-0.479(0.268)^{*}$ & & \\
\hline claim0g2 & $-0.207(0.130)$ & & \\
\hline claim181 & & $-0.001(0.000)^{* * *}$ & \\
\hline entgcens & $-0.127(0.179)$ & & $-0.254(0.234)$ \\
\hline foreign & $-0.145(0.085)^{*}$ & $-0.130(0.083)$ & $-0.284(0.090)^{* * *}$ \\
\hline frmsize1 & $-0.310(0.088)^{* * *}$ & & $-0.025(0.065)$ \\
\hline frmsize2 & $-0.174(0.078)^{* *}$ & & \\
\hline frmsize3 & $-0.049(0.103)$ & & $0.122(0.092)$ \\
\hline kids & $-0.134(0.077)^{*}$ & & \\
\hline lnage & & $-0.112(0.126)$ & $0.123(0.133)$ \\
\hline lnclaim361 & & & $-0.028(0.014)^{* *}$ \\
\hline logentg & $-0.030(0.023)$ & $0.036(0.030)$ & $-0.043(0.040)$ \\
\hline married & $-0.003(0.069)$ & & $-0.030(0.062)$ \\
\hline middle & & $-0.012(0.073)$ & $0.147(0.075)^{*}$ \\
\hline north & & $-0.151(0.071)^{* *}$ & $-0.184(0.079)^{* *}$ \\
\hline preex12cum & $0.019(0.019)$ & & $-0.043(0.022)^{*}$ \\
\hline preex 24 cum & $-0.019(0.011)^{*}$ & $0.001(0.007)$ & $0.018(0.008)^{* *}$ \\
\hline preex60cum & $0.001(0.003)$ & $0.003(0.002)$ & \\
\hline preex6cum & & & $0.036(0.049)$ \\
\hline south & & $-0.147(0.071)^{* *}$ & $-0.182(0.079)^{* *}$ \\
\hline tnull & & $-0.001(0.001)$ & \\
\hline y1982 & & $-0.222(0.094)^{* *}$ & \\
\hline y1983 & & $-0.265(0.099)^{* * *}$ & \\
\hline y1987 & & $-0.254(0.114)^{* *}$ & \\
\hline y1990 & & & $0.150(0.104)$ \\
\hline y1991 & & & $0.385(0.196)^{* *}$ \\
\hline y8182 & $0.175(0.069)^{* *}$ & & \\
\hline y 8687 & $0.361(0.060)^{* * *}$ & & \\
\hline _cons & $-2.159(0.405)^{* * *}$ & $-2.130(0.507)^{* * *}$ & $-2.676(0.533)^{* * *}$ \\
\hline$\overline{\mathrm{N}}$ & 60083 & 25711 & 15814 \\
\hline
\end{tabular}


Results for Smith and Todd (2005) Balancing Test, ST8092 Males

\begin{tabular}{l|llll}
\hline \multicolumn{5}{c}{ Treatment ST8092, Female=0, Cubic of Pscore } \\
\hline & P-values $>.1$ & P-values $>.05$ & P-values $>.01$ & Regressors \\
\hline Stratum 1 & 27 & 29 & 29 & 29 \\
Stratum 2 & 22 & 23 & 24 & 24 \\
Stratum 3 & 18 & 18 & 18 & 18 \\
\hline
\end{tabular}

Treatment ST8092, Female=0, Quartic of Pscore

\begin{tabular}{l|llll}
\hline & P-values $>.1$ & P-values $>.05$ & P-values $>.01$ & Regressors \\
\hline Stratum 1 & 22 & 26 & 29 & 29 \\
Stratum 2 & 21 & 24 & 24 & 24 \\
Stratum 3 & 15 & 18 & 18 & 18 \\
\hline
\end{tabular}


Participation Probit for ST8092, Females

\begin{tabular}{|c|c|c|c|}
\hline & Treatm & 2, Female $=1$ & \\
\hline & Stratum 1 & Stratum 2 & Stratum 3 \\
\hline$\overline{\mathrm{BER} 2}$ & & & $0.024(0.088)$ \\
\hline BER3 & & & $0.163(0.083)^{*}$ \\
\hline BIL1 & $0.477(0.172)^{* * *}$ & & \\
\hline BIL2 & $0.443(0.180)^{* *}$ & & \\
\hline BIL2a3034 & $-0.148(0.150)$ & & \\
\hline BIL2a3544 & $0.171(0.086)^{* *}$ & & \\
\hline LAND11 & & $-0.181(0.110)^{*}$ & \\
\hline LAND8 & $0.187(0.060)^{* * *}$ & & \\
\hline WZW3 & $0.094(0.085)$ & $-0.141(0.114)$ & \\
\hline WZW6 & & $0.029(0.077)$ & \\
\hline WZW7 & & $-0.170(0.087)^{* *}$ & \\
\hline a3034 & $0.322(0.123)^{* * *}$ & & \\
\hline a3544 & & $0.123(0.069)^{*}$ & $0.124(0.067)^{*}$ \\
\hline claim0g1 & $0.578(0.356)$ & & \\
\hline claim0g2 & $0.861(0.449)^{*}$ & & \\
\hline claim0g3 & $0.825(0.482)^{*}$ & & \\
\hline claim181g0 & & $0.933(0.308)^{* * *}$ & \\
\hline claim181g1 & & $0.772(0.183)^{* * *}$ & \\
\hline claim181g2 & & $0.573(0.146)^{* * *}$ & \\
\hline claim_361 & & & $-0.219(0.088)^{* *}$ \\
\hline entgcens & & & $0.370(0.298)$ \\
\hline foreign & $-0.277(0.121)^{* *}$ & & \\
\hline frmsize1 & $-0.119(0.064)^{*}$ & & $-0.180(0.094)^{*}$ \\
\hline frmsize2 & & & $-0.208(0.090)^{* *}$ \\
\hline frmsize4 & & & $-0.046(0.100)$ \\
\hline kids & $-0.036(0.081)$ & $0.005(0.084)$ & $0.025(0.087)$ \\
\hline lnage & $0.036(0.140)$ & $-0.155(0.150)$ & \\
\hline $\operatorname{lnclaim0} 0$ & $-0.133(0.080)^{*}$ & & \\
\hline lnclaim181 & & $0.050(0.044)$ & \\
\hline logentg & $0.087(0.036)^{* *}$ & $0.088(0.042)^{* *}$ & $0.045(0.047)$ \\
\hline married & $-0.128(0.058)^{* *}$ & $-0.125(0.061)^{* *}$ & $-0.150(0.059)^{* *}$ \\
\hline middle & & $0.133(0.080)^{*}$ & \\
\hline north & & $0.022(0.076)$ & $-0.108(0.075)$ \\
\hline preex12 & & $-0.111(0.084)$ & $0.276(0.135)^{* *}$ \\
\hline preex12cum & & & $-0.061(0.033)^{*}$ \\
\hline preex24 & & $0.174(0.078)^{* *}$ & \\
\hline preex24cum & & & $0.005(0.011)$ \\
\hline preex6 & $-0.145(0.082)^{*}$ & & $0.146(0.189)$ \\
\hline preex60cum & & & $0.003(0.003)$ \\
\hline pretx2 & & & $0.317(0.147)^{* *}$ \\
\hline south & & & $-0.265(0.075)^{* * *}$ \\
\hline tnull & $0(0.001)$ & $0.002(0.001)^{* *}$ & $0(0.001)$ \\
\hline y1984 & & $-0.256(0.130)^{* *}$ & \\
\hline y1986 & $0.294(0.084)^{* * *}$ & & \\
\hline y1990 & $0.130(0.117)$ & & \\
\hline y1991 & $0.487(0.178)^{* * *}$ & & \\
\hline y8486 & & & $0.255(0.069)^{* * *}$ \\
\hline y8889 & & $-0.245(0.099)^{* *}$ & $0.275(0.102)^{* * *}$ \\
\hline cons & $-3.572(0.576)^{* * *}$ & $-3.530(0.609)^{* * *}$ & $-2.336(0.389)^{* * *}$ \\
\hline$\overline{\mathrm{N}}$ & 35927 & 23115 & 17148 \\
\hline
\end{tabular}


Results for Smith and Todd (2005) Balancing Test, ST8092 Females

\begin{tabular}{l|llll}
\hline \multicolumn{5}{c}{ Treatment ST8092, Female=1, Cubic of Pscore } \\
\hline & P-values $>.1$ & P-values $>.05$ & P-values $>.01$ & Regressors \\
\hline Stratum 1 & 22 & 22 & 22 & 22 \\
Stratum 2 & 20 & 20 & 20 & 20 \\
Stratum 3 & 21 & 22 & 22 & 22 \\
\hline
\end{tabular}

Treatment ST8092, Female=1, Quartic of Pscore

\begin{tabular}{l|llll}
\hline & P-values $>.1$ & P-values $>.05$ & P-values $>.01$ & Regressors \\
\hline Stratum 1 & 17 & 19 & 21 & 22 \\
Stratum 2 & 18 & 18 & 20 & 20 \\
Stratum 3 & 20 & 22 & 22 & 22 \\
\hline
\end{tabular}

Figure 6: Graphical Check of Common Support for ST8092
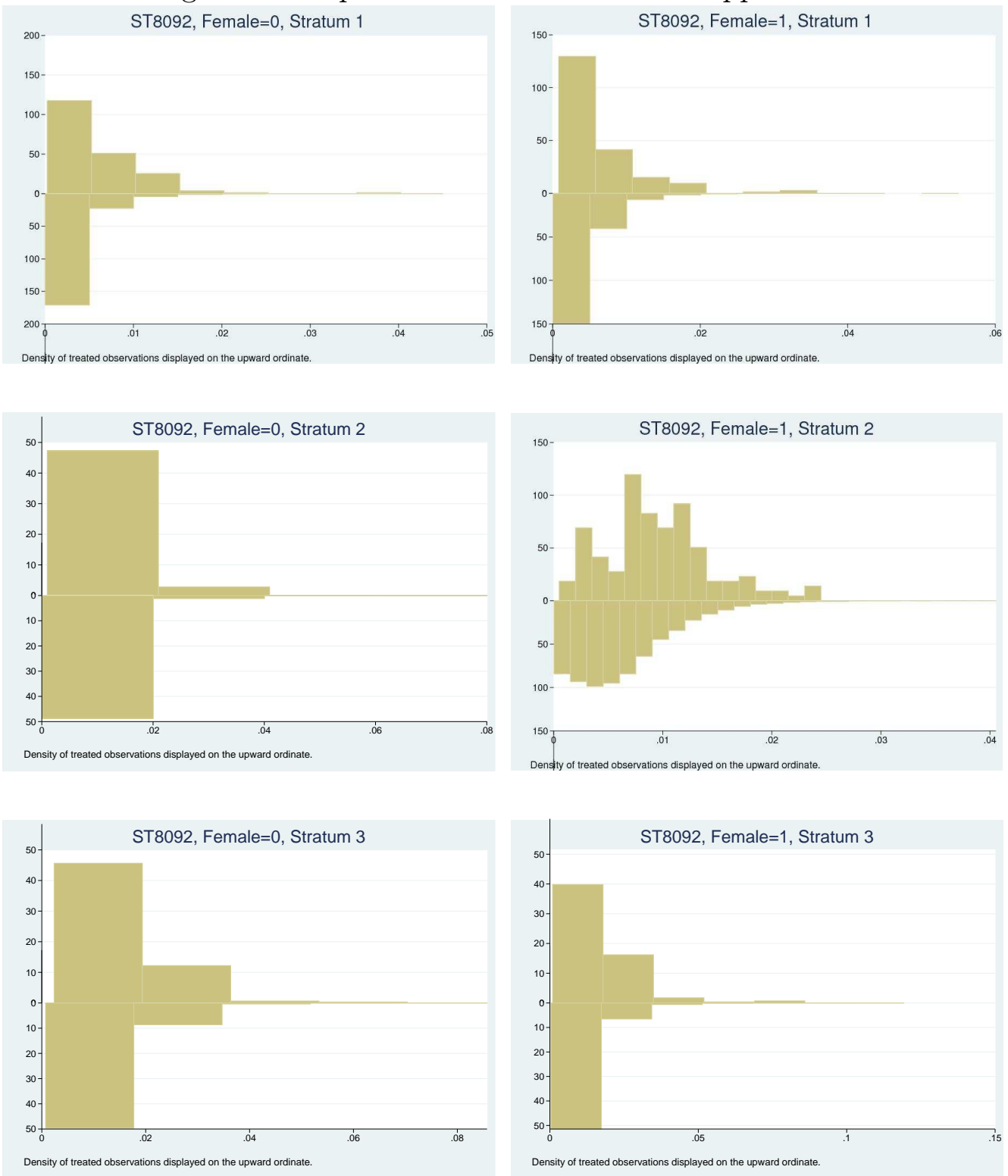